\title{
EXPLORING THE SOCIAL AND ECONOMIC DEVELOPMENT IMPACT OF THE CANADIAN SEASONAL AGRICULTURE WORKERS PROGRAM (CSAWP) FOR JAMAICAN MIGRANT WORKERS, THEIR FAMILIES AND COMMUNITIES.
}

\author{
by \\ Paulette Carol Wright, Bsc. University of the West Indies 1999 \\ A Major Research Paper \\ presented to Ryerson University \\ in partial fulfillment of the requirements for the degree of \\ Master of Arts \\ in the Program of \\ Immigration and Settlement Studies
}

Toronto, Ontario, Canada, 2013

(C) Paulette Wright 2013 


\section{AUTHOR'S DECLARATION FOR ELECTRONIC SUBMISSION OF A MAJOR RESEARCH PAPER (MRP)}

I hereby declare that I am the sole author of this Major Research Paper. This is a true copy of the MRP, including any required final revisions, as accepted by my examiners.

I authorize Ryerson University to lend this MRP to other institutions or individuals for the purpose of scholarly research

I further authorize Ryerson University to reproduce this MRP by photocopying or by other means, in total or in part, at the request of other institutions or individuals for the purpose of scholarly research.

I understand that my MRP may be made electronically available to the public.

\section{Paulette Carol Wright}




\title{
EXPLORING THE SOCIAL AND ECONOMIC DEVELOPMENT IMPACT OF THE CANADIAN SEASONAL AGRICULTURE WORKERS PROGRAM (CSAWP) FOR JAMAICAN MIGRANT WORKERS, THEIR FAMILIES AND COMMUNITIES.
}

\author{
Paulette Carol Wright \\ Master of Arts, 2013 \\ Immigration and Settlement Studies \\ Ryerson University
}

\begin{abstract}
The enthusiasm of immigrant sending countries around migration and development hinges on the fact that the flow of money, knowledge and universal ideas can have a positive effect on development in these countries. The Canadian Seasonal Agriculture Workers Program (CSAWP) was established in 1966, most of the Social Science literature on this program has emphasized its exploitative and problematic aspects. Without dismissing the significance of the focus and results of other research, this paper examines the social and economic development impact of this program on households and communities in Jamaica. Research done by academics and an analysis of Jamaica's newsprint media done for this research reveal that the CSAWP has had positive development impacts. Findings suggest that the program is delivering social and economic benefits to migrant workers and their families. It has increased income, consumption, child schooling and improved health care. In addition to improving the standard of living for migrant workers and their families, the CSAWP has additional benefits at the community and national levels.
\end{abstract}

Key words:

Social, economic, development, Jamaican migrant, seasonal agriculture worker program. 


\section{ACKNOWLEDGEMENTS}

The completion of this research project would not have been possible without the assistance and guidance of many individuals to whom I am sincerely grateful.

I take this opportunity to express my profound gratitude and deep regards to my supervisor, Professor Sedef Arat-Koc for her exemplary guidance, monitoring and constant encouragement throughout the course of this research project. I would like to thank and express my appreciation to my second supervisor Professor Galabuzi for his invaluable input, critical comments and recommendations to improve my work.

Many thanks are due to my fellow graduate students in the Immigration and Settlement program, who walked through the challenges of graduate school with me and with whom I was able to share ideas and garner valuable information. Your friendship and endless support is greatly appreciated.

Finally, I would like to thank all my family and friends for their patience, encouragement, love and prayers. In particular, I would like to express my deepest love and appreciation to my husband (Donovan Wright) and two boys (Jonathan and Nathan) who have made huge personal sacrifices for me while I was engaged in this academic research. Thanks for the emotional support and encouragement. 


\section{TABLE OF CONTENTS}

Chapter 1: An Introduction (pp. 1-3)

Chapter 2: Part 1: Literature review (pp. $4-13$ )
a. Migration and development
b. Remittances and development
c. Effects of remittance at the household level, community and national levels
d. Social remittances
e. skills and knowledge transfer

Chapter 2: Part 2: Literature review (pp. 14-19)

History and characteristics of the Canadian Seasonal Agriculture Workers Program (CSAWP)

Chapter 3: Contextual review on Jamaica (pp. 20 - 31)
a. History of Jamaica (colonization, slavery, independence)
b. The Jamaican economy
c. The role of the International Monetary Fund in destroying the Jamaican economy
d. Migration as a survival strategy in Jamaica
e. Reasons the CSAWP is important for Jamaica

Chapter 4a: The use of newspapers in research and Research Findings (pp. 32 - 47)
A: Methodology
b: Discussion and analysis
1: Media representations of Jamaican's perspective on migration
2: Jamaican media representations of the CSAWP
3: Jamaican media representations of CSAWP and its impact at the household, community and national levels
4: Transfer of knowledge and skills

Chapter 4b: Academic literature on the cost and benefits of the CSAWP to Jamaican migrant workers, their families, communities and Jamaica as a whole (pp. 48 - 53)

Chapter 5: Conclusions and Recommendations (pp. 54 - 56)

$$
\text { Appendices (pp.57 - 61) }
$$

References (pp. 62 - 68) 


\section{LIST OF APPENDICES}

1. Appendix A Positive and negative opinions on the CSAWP

2. Appendix B Map of Jamaica

3. Appendix C Graph showing Jamaica's unemployment rate

4. Appendix D Pictures showing the popularity of the CSAWP in Jamaica

5. Appendix E List of acronyms 


\section{Chapter 1: INTRODUCTION}

Migration has been one of the defining features of Jamaica since colonization. In the post independence period and especially since the 1980's, Jamaica has been faced with a number of challenges hindering its development. This is reflected in the high levels of unemployment and poverty the country faces. Most Jamaicans feel that their family's' financial situation is deteriorating and will continue to worsen. The unavailability of sufficient jobs in Jamaica has led to large out migration of its population for work and a reliance on migrants for social and economic assistance mainly through remittances and skills transfer. Economic opportunities, access to better services elsewhere and disparities in economic development and social conditions are the main factors that have attracted Jamaicans to countries within the region as well as more attractive international destination. While many Jamaicans migrate permanently, others have utilized temporary or circulatory migration in order to obtain a better life for themselves and their families. One of the most popular temporary worker programs that Jamaicans participate in is the Canadian Seasonal Agriculture Workers Program. (CSAWP)

The CSAWP is one of Canada's most established and long standing temporary worker programs. Every year the Canadian government facilitates the recruitment of thousands of seasonal workers from Jamaica. The program which began recruiting in 1966 has allowed temporary Jamaican migrant workers to work in Canada for a period of six weeks to eight months each year. The program is presented as aiming to provide a win-win outcome where the participating countries' migrants benefit from employment and remittance inflows and the employers benefit from productivity gains and a reliable supply of workers for their agricultural industry. Since its inception, the CSAWP has not only expanded in size and source countries but it has become acclaimed as a model for temporary worker programs in Canada as well as in Europe. 
In spite of being held in such high esteem, the program has been criticized by activists and academics who have brought to light major issues with its structure, administration and monitoring. The CSAWP has been charged with being based upon discriminatory immigration policy that restricts personal freedoms and labour rights of migrant workers. Tenuous living and working conditions and health and safety concerns have been emphasized. This research is not aimed at providing justification for a labour program that many people call "exploitative". Rather it focuses on the actual and potential economic and developmental benefits that the program offers for Jamaica and Jamaica workers. While recognizing the restrictions and the challenges associated with the program, Jamaican migrant workers accept the conditions of employment as a trade off for the opportunity of advancement often not available to them in Jamaica.

The central aim of the research for this project has been to ascertain the social and economic developmental impact of the CSAWP on Jamaican migrant workers, the migrant's households, their communities, and Jamaica as a whole. Through the use of Jamaica's newsprint media dated between January, 2005 and March, 2013 and previous research on the cost and benefits of the CSAWP done by academics, I seek to find out how the program has impacted the living standards of Jamaican farmers, their families and communities and how the program has proven to be beneficial to migrants and their families on both a short term and a long term basis. The findings of the media analysis conducted reveal that the CSAWP is generally perceived as a developmental program recognized for the positive role it plays in providing income earning opportunities for migrant workers and being a source of income generation for workers communities and the country as a whole. 


\section{Organization of the paper}

Following this introductory chapter, Chapter 2 is divided into two sections. The first section provides a review of the existing literature. It explores the nexus between international migration and development, the impact of remittances as well as the effects of knowledge and skills transfer on countries of origin. The second section of chapter two focuses on the specific history and characteristics of the Canadian Seasonal Agriculture Workers Program (CSAWP). Chapter 3 provides the background for the research. A contextual review on Jamaican history is conducted. Here the history of Jamaica (colonization, independence), Jamaica's economic situation and the role of the International Monetary Fund in influencing Jamaica's economic conditions are examined. Migration as a survival strategy in Jamaica and the importance of the CSAWP for the country is then assessed. Chapter 4 presents the methodology and research results from the media analysis. It discussed how Jamaican print media and academic research talk about migration and development in general and the cost and benefits of the CSAWP on Jamaican families, communities and the country in particular. The conclusion summarizes the key points from the research and looks at some of the essential issues that can be implemented to improve life for Jamaican migrant farmers and facilitate further development in the country. 


\section{Chapter 2 - LITERATURE REVIEW}

The social and economic impact of migration on countries of origin

Migration is not a new phenomenon, according to Massey et. al. (1998) migration is as old as humanity itself. People have always moved from one place to another to explore, to search for better economic opportunities both within and outside of their homelands or because of what is referred to by Hau' ofa (1993) as mobility engrained in a people's heritage. Castles and Miller (2003) argue that, today, economic globalization has put a new spin on international migration, making the flow of people across borders much easier, faster and more frequent on a scale that was not previously possible.

According to the International Organization for Migration (2011), over the past few decades the number of international migrants in the world has increased rapidly, measuring the highest ever recorded figure of an estimated 214 million international migrants in 2010. The increase in migration involves less permanent and settlement migration and has been replaced by temporary and circular migration. Santos (2003) states that this is because, host countries have redirected their immigration policies toward stricter conditions of admission for immigrants. The general trend is an increase in the share of temporary visas issued relative to permanent visas. In recent years, Canada too has made a shift to temporary migration. In 2008 for the first time, the number of temporary foreign workers in Canada $(251,235)$ exceeded the total number of permanent residents $(247,243)$ admitted in the same year (CIC, 2009).

Basok (2007) states that compared with permanent forms of migration, policy makers consider temporary forms of migration more attractive for a number of reasons. In particular temporary 
migration permits greater flexibility in the labour market and can seem more acceptable to electorates that find permanent migration 'threatening'. Basok (2007) stresses that; a less considered reason among destination countries is the development impact of migrants remitting income. The positive potential role of migration in the development process has been recognized, in particular, the contribution of migrants through remittances, skills transfer and the development of transnational networks.

\section{Migration and Development}

According to the International Organization for Migration (2011), migration and development are interdependent processes which profoundly influence one another. International migration in the development context relates both to people who have chosen to move of their own accord, and forced migrants who can ultimately end up contributing to both their country of resettlement and possibly their country of origin. Development, meanwhile, is a dynamic process implying growth, advancement, empowerment and progress, with the goal of increasing human capabilities and enlarging the scope of human choice (IMO, 2011). In the development process, it is important that people's productivity, creativity and choices are broadened, and that opportunities are created for them. Sen (1999) argues that income growth itself should not be the litmus test for development, but one should question whether or not the capabilities of people to control their own lives have expanded. Though agreeing that incomes can have a high potential to contribute to development, Sen stresses that the relationship between income and human development is by no means direct or automatic, making income indicators alone an inadequate indicator of the quality of people's lives.

Findings on the effects of migration on development differ. It is possible to distinguish two contrasting views concerning the assumed benefits and shortcomings of migration. One view considers that the overall impact of out migration on migrant sending countries is negative and recommends designing 
policies to promote employment and development in order to limit population movements from these areas (Deshingkar and Grimm 2005). Supporters of this view focus on the negative impact of labour loss in the sending countries and its disruptive effect on the local economy.

A second view considers that migration can have a positive impact on development at the local, regional and national levels. This view emphasizes the benefits arising from the transfer of resources to the country of origin such as financial or in-kind remittances, as well as the generation and transmission of new skills and innovative ideas. Individual and collective remittances contribute to the subsistence and well-being of rural families and create employment opportunities directly and indirectly (Sorensen, 2004). Accordingly, it is recommended that policies be designed to increase the social, economic and financial links between migrants and their communities or countries of origin.

Vargas-Linduis, R. et. al. (2005), found that migration is generally a household decision and is a highly complex procedure that considers: potential benefits; family; social and economic costs; changes in the division of labour; migration policies and rules; availability of networks; and many other aspects that may facilitate decisions to leave. Household members tend to act collectively not only to maximize and diversify income, but also to minimize risks and loosen constraints created by a variety of market failures. In line with the new economy of labour migration theory and livelihood approaches, most recent empirical research supports the view that labour migration, rather than being a response to destitution or absolute poverty (Hampshire, 2002), is a livelihood strategy pursued by households in reaction to relative deprivation (Stark and Taylor, 1989); in order to spread livelihood risks; secure and increase income and acquire investment capital. Migration can be a potential means to diversify economic activities to overcome risk and obtain liquidity and capital (Hampshire, 2002). Remittances are central elements in such household strategies to overcome local development constraints. 


\section{Remittances and development}

Remittances are an important and stable source of income for many households in developing countries. According to the World Fact book (2012), remittances are the key mechanisms through which migrants transfer a part of their net earnings to those remaining in the home country. They comprise money transfers from abroad, gifts in kind sent by migrants, and both money and gifts brought home by returning migrants. Studies have shown that there is great scope for temporary migration schemes to promote development, as migrants who intend to return home are more likely to make remittances and send a higher proportion of their income back to their country of origin. According to Louka (2006), migrants who leave their immediate families behind remit far more than when the family accompanies them. The intent to return to their family is a key factor in motivating high savings and remittances. According to De Hass (2007), remittance transfers have been identified as having the potential to contribute significantly in migrant-sending countries. Taylor et al. (1996) state that through remittances, migrants may directly contribute to the economy in their home country through a greater purchasing ability of goods and services, as well as assisting indirectly through the stimulation of production. O'Neil (2003) found that after foreign direct investments and trade related earnings, remittance transfers make up the largest financial flow into developing countries, and far exceed official development assistance flows. In 2011 worldwide remittance flows including flows to developing countries and high income countries were estimated to be $\$ 483$ billion. Of this amount, developing countries received $\$ 351$ billion (Ratha 2012). The World Fact book (2012) points out that this constitute more than 10 percent of gross domestic product (GDP) in many developing countries. Worldwide remittance flows are expected to reach $\$ 593$ billion in 2014 (Ratha 2012). Ratha (2007) and Taylor (1999) state that, calculating the true development impact of remittances have proven difficult due to unreliable figures provided by developing countries and the level of remittances that are sent 
through informal channels. The general consensus in the literature however, is that remittances contribute positively to family and household incomes especially in countries that provide a 'fertile ground' for migration and remittances.

\section{Effects of remittances at the household level}

At the household level, remittances often have a positive development effect. Remittances generally improve the standard of living, they increase and diversify income and allow household members to allocate more resources to providing food, accessing health services and sending their children to school. Ratha (2005) asserts that remittances can play an effective role in reducing poverty in developing countries as remittance transfers usually go directly to the families of migrants. According to MacLellan (2009) migrants' earnings directly benefit their families by constituting more than 50 percent of their household income in some cases. He states that remittances have been playing an important role in developing countries by boosting economic growth and reducing poverty as well as enabling the recipient family to increase consumption. He claims that remittances alleviate the hardship of poverty by supporting family budget and basic consumption. Remittances also lead to increased investments in health, education, and small businesses. Research has established that remittance transfers are mainly spent on housing, education, healthcare and everyday expenses (De Hass, 2005;

O'Neil, 2003). However, once basic needs are met, families constructed or expanded their houses and started small businesses (Knowles, 1999).

Opinions diverge regarding the effects of migration and remittances on health and education. Some researchers have found that the health and educational status of children belonging to migrant households tends to improve with remittances, while others emphasize that the impacts of migration are not always positive and that the social and human costs for future generations are high. On the whole, 
studies have shown that remittances have a positive impact on health. A study carried out in Mexico and Jamaica verified that children born into international migrant households in rural areas were less likely to die during their first year and that they had a higher birth weight than other children. It was also verified that the children had gained improved access to medical care, particularly since migration had increased their parents' and relatives' awareness of the importance of health care (Vargas-Linduis, et. al. 2008 and McLaughlin, 2009). Other studies for example, McKenzie (2006) however, have highlighted the negative health impacts of psychological troubles and difficulties triggered by parental absence, as well as the spread of infectious diseases and careless attitudes towards children's health when they have been left with friends or distant relatives.

Findings indicate that children from remittance-receiving households are much more likely to be enrolled in school than their counterparts from other households. While assessing school enrolment and attendance in Mexico, it was found that children from migrant households are more likely to attend school; more likely to stay in school in the age range in which school dropout rates peak; have higher completed grades; and overall better progress than children from non-migrant households (Özden et. al. 2005). Nevertheless, negative connections between remittances and education have also been observed. Research has identified overall negative impacts of migration on education, particularly in rural areas, recording that the disruptive effects of migration on family life have hampered children's school performance (McKenzie, 2006).

A further potential benefit of remittances is that these transfers may also act as a form of insurance. The idea is that when the family left at home hits hard times for some reason beyond their control; a member who has migrated can transfer support home in the form of remittances (Louka, 2006). 


\section{Effects of remittances at the community level}

According to MacLellan (2009) increased household consumption, especially in the form of expenditure on health, education and family welfare, contributes to human welfare and capital development at the community level. Various empirical studies have reported that return migrants build or repair homes and that these construction activities can generate considerable employment and income for non-migrants. In this way, the benefits of remittances might accrue to households other than the ones that directly receive them. De Haas (2007) and Stark and Bloom (1985) highlight that these expenses increase consumption levels, that may by easing capital and risk constraints on local production, in turn facilitate local investments by migrants and non- migrants alike. In this way, expenditure on housing and consumption may have significant multiplier effects in the wider economy. De Hass (2007) argues that, in this sense remittances can be seen to represent a 'bottom up' form of development finance which may prove more effective in enhancing social and economic development at the grassroots level than traditional forms of development aid. In addition, Louka (2006) states that the families of migrant workers have gained respect and status in their local communities as a result of their enhanced capability to contribute to growth.

\section{Effects of remittances at the national level}

At the national level, there is substantial evidence that remittances are an increasingly important and relatively stable source of external finance that often play a critical social insurance role in countries afflicted by economic and political crises (Kapur, 2003). Remittances have proved to be less volatile and therefore, a more reliable source of foreign currency than other capital flows to developing countries such as foreign direct investment and development aid. Remittances often cover an important part of developing countries' trade deficits. In addition to their significance as a source of foreign currency, remittances can also improve a country's creditworthiness for external borrowing, and they 
can expand access to capital and lower borrowing costs (World Bank, 2011).

\section{Social Remittances}

According to Levitt (2010) social remittances are defined, as ideas, practices, mind-sets, world views, values and attitudes, norms of behaviour and social capital (knowledge, experience and expertise) that migrants consciously or unconsciously transfer from host to home countries. Social remittances circulate in several ways: when migrants return to live in or visit their communities of origin; when non migrants visit their friends and family in a receiving country; or through letters, videos, e-mails, and phone calls. Migration often causes comprehensive social, cultural and political changes. Migrants learn about and experience the various cultural attitudes, practices and political ideas in countries of destinations. Their families and communities may positively adapt to some of these new attitudes and apply the lessons learned; while other novelties and innovations may create conflicts within households and communities.

Levitt (2010) suggests that social remittances shake up gender and generational dynamics in ways that benefit women. She states that migrant men and women throughout Latin America and Asia, who work and share responsibility for housecleaning and child care, talk about and model gender relations differently when they visit or return to their home communities. When women move their role as caregivers changes, and men have been found to be more likely to engage in reproductive activities

such as caring for the children and the elderly (King \& Vullnetari 2006). When the men emigrate, women are empowered to take more prominent part of the community decision making, control their own income, and expand their role in the domestic sphere (Deshingkar \& Grimm 2005, p. 39).

Kramer (2004) said men reported that time away from their families resulted in an enhanced appreciation for spouse and children, and that performing 'female' household chores, such as washing 
and cooking often for the first time while away, contributed to a re evaluation of these activities, as well as a greater willingness to chip in when at home. Males claim to express affection to their companions more openly, they apparently treated their wives with more respect and they seemed to make more decisions together (McLaughlin, 2009).

According to a study done by Levitt (2010) on a village in the Dominican Republic, and Jamaica Plain, a neighbourhood in Boston, where many Dominicans settled, social remittances influence health outcomes. Because Dominicans earned more money and received more education in the United States, many people became more health conscious. They were more likely to eat healthier and recognize the importance of annual check-ups because they were entitled to them through their medical insurance in the United States. In addition, attitudes toward education can also shift. As more young people from Dominica completed high school and went on to higher education in the United States, their nonmigrant peers also wanted to go to college. As young people ventured into a wider range of careers, it became more acceptable to study international relations and humanities instead of just finance, medicine, or pharmacology (Livett 2010).

\section{Skills and knowledge transfer}

The transfer of knowledge and skills or brain circulation is perceived to be a positive outcome of circular migration. In addition to financial gains, migrants learn skills and gain knowledge during their work experience overseas through their participation in social, cultural and economic activities. Billet (2004) states that the learning can be understood as permanent or semi permanent changes in how migrants think and act. Learning is inherent in everyday thinking and acting, as such all experiences either reinforce what is already known or contribute to new skills and knowledge. The knowledge and skills migrants gain may be transferred to their home communities. They also enhance migrants' 
success during repeat contracts in host countries reflecting migrants' cultural adaptability, the ability to move and adjust successfully to the cultural settings of both sending and receiving countries. Belford et. al. (2009) emphasize that the focus on industry specific skills can risk ignoring non industry specific skills migrants may gain including financial skills such as money management, language skills and intangible skills such as time management. Learning these skills are essential to personal growth and enable migrants to function more effectively in both their home and host countries.

Today, migration and development are increasingly gaining popularity around the world. Although Vertovec (2009) cautions, that the positives of migration might seem generous in terms of fulfilling labour shortages, economic development and public opinions, and warns that there remain challenges and the positives might be overly praised, developing countries are utilizing migration as a way to escape poverty and enhance the quality of their citizens lives at the household, community and national levels. 


\section{Chapter 2 b:}

Several researchers for example (Prebisch and Grez, 2010; Ferguson, 2007; Kramer, 2004; and Veena, 2003) have suggested that the securing of skilled, reliable and affordable labour to ensure successful growing seasons in Canada's agriculture sector has been a perpetual challenge and will continue to be a dilemma. Veena (2003) highlights the fact that there is no shortage of low skilled Canadian workers, but rather the shortage is qualitative in that even unemployed Canadians refuse to work in agriculture because of low wages and difficult working condition. Farm work is not the career of choice for most Canadians. Ferguson (2007) states that seasonal farm work, seen as difficult, dirty, and dangerous, is typically not attractive to Canadians who can find year round work with higher wages, more benefits, and opportunity for upward mobility.

Several attempts were made by the Canadian government to recruit domestic labour in order to fill vacancies in the agricultural sector before the introduction of the Seasonal Agriculture Worker Program. Each attempt to recruit and maintain domestic workers failed as workers would demand pay increases, quit during peak harvesting periods and as they "lacked discipline and commitment to the farm" as perceived by the farmers (Basok, 2002: p. 18). As a result, farmers lobbied for a program to recruit foreign contract labour in order to have a pool of cheap and reliable labour force. Early attempts which (began in 1947) to recruit Caribbean migrant workers were met with hostility. Satzewich (1991), states that between 1947 and 1966 the decision not to allow Canadian farmers to make use of Caribbean migrant labour was shaped by the idea of race and an ideology of superiority and inferiority. Satzewich argues that, Caribbean migrants were defined as a qualitatively different race of people, possessing certain negatively evaluated traits. Their mere presence in the country was seen to constitute a threat to social order and therefore, the state was unwilling to allow them even temporary entry (Satzewich, 1991). 
In light of acute labour shortages and increased pressure from the farm lobby, the federal government finally relented and the Canadian Seasonal Agriculture Workers Program (CSAWP) was born. The CSAWP was developed in 1966 by Human Resources and Development Canada (HRDC) in cooperation with Citizenship and Immigration Canada (CIC) (Greenhill, 2000). It is described as a formal program of 'managed' circular migration (Veena, 2007) and has been in existence for forty six years. The CSAWP facilitates the temporary migration of agriculture workers into Canada for periods of 6 weeks to 8 months, to meet farmers' demand for low skilled labour. It started as a pilot project between Canada and Jamaica and allowed for 264 Jamaican workers to come to Canada temporarily to harvest tobacco in Southern Ontario (Hanley, 2007). The program, which has expanded significantly now include, Barbados and Trinidad and Tobago which joined in 1967, Mexico in 1974 and countries in the Eastern Caribbean states of Dominica, St Lucia, St. Kitts and Nevis, Grenada and Saint Vincent and the Grenadines in 1976. Recently workers from Guatemala, Honduras and El Salvador were recruited to work on farms in Canada. According to Flecker (2011), while the influx of these workers was relatively small in the 1970s with around 4000 workers, it had grown to about 29,000 in 2009.

According to Russel (2009) and Veena (2003), the seasonal agriculture workers program was established with the objectives of; meeting qualifying farmers seasonal demand for low-skilled agricultural workers during the peak planting and harvesting season; improving economic prosperity and global agricultural trade competitiveness of the Canadian horticultural industry through timely crop planting and harvesting; improving the economic well-being of the migrant agricultural workers by giving them access to better paying seasonal jobs in the agricultural sector at relatively higher wages than they could obtain from similar or alternative activities in their home countries; and finally facilitating the return of the workers to their home countries at the end of their temporary employment in Canada. 
The CSAWP is managed and implemented within a three-tier institutional framework. At the federal level, the program is implemented within the framework of the Immigration Refugee and Protection Act and Regulations and a labour market policy premised on the "Canadians First" principle. At the provincial level, statutes relating to employment standards, labour and health govern program implementation. The program is also implemented within bilateral administrative arrangements between Canada and the source countries. These arrangements are formalized in Memoranda of Understanding (MOUs) and Employment Contracts between FVH growers and migrant workers and the Government Agents of the supply country (Veena, 2003).

Originally, the Seasonal Agriculture Workers Program was managed by Human Resources and Development Canada (HRDC). During the 1970's and the first half of the 1980's a program quota was set by the department and announced each year (Greenhill, 2000). This arrangement helped to alleviate some of the labour shortage; however, by the mid 1980's the system was beginning to breakdown. The department recognized that despite the time, effort and money invested at resolving the labour shortages, efforts were costly, labour intensive and largely ineffective. Seasonal agricultural labour shortages were continuing to grow as the labour market heated up; Canadian agricultural workers were continually being lost to competing sectors which offered better wages, better working conditions and full time status rather than seasonal employment. It had become obvious that fundamental changes needed to be made to the program if they were going to remove the quota in favour of a supply and demand driven model. In 1987 the HRDC decided to give the private sector an active role in the administration of the program and so the program was privatized (Greenhill, 2000).

In Ontario and Nova Scotia, the Foreign Agricultural Resource Management Services (FARMS), a non- 
profit organization control and funded by Canadian growers administers the program and the Foundation of Enterprises for the Recruitment of Foreign Labour, (FERME), functions in the same capacity for Quebec, New Brunswick and Prince Edward Island (Ferguson 2007). According to Flecker (2011) once producers took control of the program, the quota system, which previously limited the number of workers admitted to Canada, was dropped in favour of an employer demand /country supply approach. It should be noted that the majority of the migrant workers (85 - 90\%) under CSAWP work in Ontario (Verna, 2007).

Today, requests for workers are made by farmers in Canada and countries respond by inviting workers to apply for screening and selection. Recruitment of farm workers is now administered by officials from countries of origin working with Canadian farmers. According to Russo, (2012) the recruitment process on the Canadian side specifies certain minimal requirements including experience in farming and being over the age of eighteen. Employers generally require participants to have dependents in order to participate in the program. This recruiting preference result in a workforce that is willing to work more hours. Having dependents in the home country is seen as a strong incentive for SAWP workers to maintain their employment, to send remittances home, and to recognize and accept the precariousness of their position in Canada (Russo, 2012).

The process of hiring seasonal agriculture workers begins with an employer completing a Labour Market Opinion (LMO) Form. One of the basic purposes of the LMO form is to show that the employer has made efforts to "recruit and or train willing and available Canadian citizens and permanent residents" for the position(s). To that end, the government asks for a human resources plan, providing details of farm recruitment activities for Canadians in the relevant season including methods used to hire local workers or students. 
The program provides a process whereby employers may request workers by name to return to work on their farms in subsequent seasons. These orders serve the farmers' interests and are processed as priority. Named workers are considered a valuable supply of experienced workers. Flecker (2011) states that approximately $70 \%$ of farm workers return as named participants. The named worker process gives workers the reasonable expectation of returning the following year and provides some level of security for future employment, thereby reducing incentives for illegal settlement. This system also fosters paternalistic relationships between workers and their employers. Loyalty of workers to their employers results in workers not wanting to abandon their employers and, therefore, lowers the chances of non-return (Verma, 2007). The drawback of this process is that a farmer can deliberately choose to exclude certain workers from their employment with no rationale.

Some other key features of the program are that the employer is responsible for providing clean living accommodations for the workers, without cost. These accommodations must satisfy the health and housing standards of the province in which the farm is located. It must also meet the expectations of the liaison service, which represents the Government of the country of origin in Canada. The cost of return airfare is to be paid for in part by the employer and employee. For healthcare, migrant workers are to be covered under provincial health care programs. In terms of other benefits, though migrant workers do pay into the national income tax, employment insurance, and the pension fund system through deductions on their pay cheques, this usually does not translate into adequate coverage or full access to the benefits which they have paid into (Flecker, 2011)

The Canadian Seasonal Agriculture Worker Program is not without its problems. Despite the importance of the agricultural sector to the Canadian economy, SAWP workers do not have the 
opportunity to apply for permanent residence status. According to Veena (2003) the Canadian government's requirement that workers remain in Canada only on a temporary basis, with no prospect of citizenship, was grounded in earlier explicitly racist immigration policies. The United Food and Commercial Workers' Union in Canada says the exploitation of migrant workers under CSAWP is a 'shameful little secret'. Poor wages, poor and unsafe working conditions, long hours of work, the lack of protection under provincial labour standards legislation and the absence of habitable accommodation are some of the problems workers face (UFCW, 2002). The accommodations, which are typically provided by employers, are considered temporary residences, and thus often lack the infrastructure of permanent dwellings. Migrant workers have very little recourse to improve shortcomings, as their landlord is also their employer (McLaughlin, 1999). This problematic conflation of the roles of employer and landlord gives employers an exceptional amount of control over the lives of seasonal agriculture workers outside of the workplace. Workers' homes are commonly placed in close proximity to their employers' homes and they may enter the workers' residences at any time. Some restrictive employers deny workers the right to even leave the property without explicit permission (McLaughlin, 1999). 


\section{Chapter 3: CONTEXTUAL REVIEW ON JAMAICA}

History of Jamaica: (Colonization, Slavery and Independence)

Jamaica, a small island of 4411 square miles $(10,991 \mathrm{sq} \mathrm{km})$, is known around the world as a tourist destination, but Jamaica has a much greater legacy. As a country, Jamaica has endured, adapted to, and in some cases overcome historical experiences of colonialism, population depletion, and slavery, and has still managed to secure a place in world affairs by excelling in sports, cultural contributions and social, political, and economic advancement (Bank of Jamaica, 2002). Despite these achievements, Jamaica, has struggled and continues to struggle to maintain a healthy economy. Despite the advances, there are high rates of unemployment and high levels of disparity in wealth. Most of the profits of growing industries landed in the pockets of foreign investors (Bank of Jamaica, 2002).

The history of Jamaica is crucial to understanding the country's current state characterized by high levels of unemployment, marginalization and poverty. Borrelli (2002) states that the roots of these problems can be found within the country's long legacy of colonialism extending 300 years in length before reaching independence. Flanagan (2009) states that the beginning of colonization in Jamaica was the step that paved the way for hundreds of years of slavery and oppression of Africans, and is ingrained into the nation's history, politics and collective identity. It all started in 1494 when Christopher Columbus arrived on the island and the Spanish took control of Jamaica.

During the reign of the Spanish, the colonizers managed to wipe out the entire population of native Tianos, comprised of approximately 60,000 people with diseases, malnutrition and slavery (Borrelli, 2002). In the 1660's, after a five-year struggle against the Spanish crown, the British won power and gained control of Jamaica. 
By the late 1600's the British were importing a large number of slaves to work on sugar plantations in Jamaica. This was achieved through the infamous triangular slave trade. According to Manley (1975, p. 12) "Jamaica was the meeting place of two populations: the British uprooting himself in search of quick wealth through sugar; and the African uprooted by force from his environment to supply slave labour upon which his owner's dream of wealth depended". The Bank of Jamaica (2002) reports that during the years of slavery, the Jamaican economy was constructed in such a way that all benefits were returned to the mother country. The economic benefits of slave labour were sent directly back to Britain while the tiny island was forced to import all imaginable goods from Britain, doubling the returns for the motherland while depleting the island of its resources and wealth. This created a model of economic dependence, a model that rooted itself solidly and still affect the country today (Bank of Jamaica, 2002).

Following emancipation of slavery in the 1830's the plantation economy continued to dominate the region. Some freed slaves went to live in the hilly regions of Jamaica, while others continued to work on the plantation for subsistence wages (Knowles, 1997). Blacks had trouble acquiring land because planters were still the owners and were reluctant to sell because it affected their prosperity. Lying and manipulation by the whites made it difficult for many blacks to acquire titles that were needed to possess land. Flanaghan (2009) states that this deception and insecurity can be seen as the foundation for the dramatic amount of "agricultural malpractice" that is still very prevalent today. Poor peasant farmers still farm on hillsides which yield very little returns, while the best lands are used for profit based agriculture and tourism establishments by large multinational organizations.

Jamaica has a very unequal class structure and majority of the $90 \%$ of blacks remain poor. Persaud (2001 p. 72) argues that the legacy of the plantation has survived to present day and 
suggests, that "the plantation system, the totality of institutional arrangements surrounding the production and marketing of plantation crops, has seriously affected society in Jamaica". In other words, the slave mode of production was a crucial factor in the establishment of Jamaica's class structure. Today, “Jamaica’s class structure reflects its history as a colonial plantation society, and the beginnings of industrial development characterized by a high rate of inequality and poverty" (Waters, 1985 p. 26).

Even though Jamaica is now an independent nation, it continues to rely on the British and much of the British institutions are still in place. The economic system and thus the political policy are directed from the outside. The transition from formal colonialism to one of constitutional independence did not end the poor people's struggle but instead enabled the British colonial rule to "reassess the local arrangements for supervising the colonial economy" (Campbell, 1987, p. 86). This reassessment provided for more colonial domination. "Freed from the British in 1962, Jamaica became an uncharted economic entity, with the responsibilities but not the means for true independence" (Nicholas, 1996, p. 18). In essence, the nation shows the external signs of political independence yet remain economically dependent.

\section{The Jamaican Economy}

With current debt burden at about 130 per cent of gross domestic product (GDP); unemployment at its highest level in 20 years, a sliding Jamaican dollar, a depleting Net International Reserve (NIR) and huge balance of payment problems; Jamaica's economic problems did not occur overnight. According to Haughton (2012) Jamaica saw its first major economic crisis in the 1970s as a result of rising world oil prices. Then came the second in the 1990s with the financial crisis, after economic liberalisation without sufficient control mechanism in place. This was only the start of a spiralling debt crisis. 
Balance-of-payments shortfalls were financed increasingly through very large capital inflows in the form of concessional loans from multilateral and bilateral lending agencies. The IMF was the largest source of balance of payments support.

According to Johnson and Monticeno (2012) Jamaica had the one of the highest interest payments as a percent of GDP in the world in 2011. The Economy Watch (2010) posits that this exceedingly large debt burden has effectively displaced most other public expenditure. Debt servicing has taken up nearly 50 percent of total budgeted expenditures over the last four fiscal years while health and education combined have only been around 20 percent. According to CIA World Fact book (2013), debt-servicing costs still hinder the government's ability to spend on infrastructure and social programs. The continuous lack of proper infrastructural development reduces the country's ability to adopt new technology, reduces its ability to increase productivity, resulting in a very inefficient economy with little or no growth (Haughton 2012). This situation is especially problematic for a country at Jamaica's income level, as it should be able to invest in infrastructure and human capital, as well as having the financial flexibility to respond to frequent natural disasters and other external shocks.

The overall unemployment rate in 2012 was $14.2 \%$, while, $16.5 \%$ of the population live below the poverty line (World Fact book, 2013). The Jamaican economy is heavily dependent on remittances which account for nearly $15 \%$ of Gross Domestic Product and exports of bauxite and aluminium make up about 10\%. Russell (2009) points out that the rates of underemployment are not given in the official statistics, but when these are factored into the unemployment and underemployment statistics, the need for employment is significant and acute. Faced with such hardship, Jamaicans who are unemployed and who have families to care for must seek alternatives in order to survive. Jamaicans move to other countries to find jobs in order to make life easier for themselves and their families. The Canadian 
seasonal agricultural worker program with all its challenges is one such alternative.

\section{The Role of the IMF in destroying the Jamaican economy}

The IMF has contributed to the breakdown of the Jamaican economy. Borrowing from the IMF has placed Jamaica into greater debt, leading to further debt servicing requirements. This has depleted the government's revenues, putting the country into a winding circular trap. Money goes toward repaying loans rather than investing in ventures which can create employment, as a result, fewer jobs are created resulting in increased out migration of Jamaicans to find work.

According to Melville (2002) in the early period after independence, the Jamaica government set about restructuring the society and sought to raise the mass of the population from poverty through aggressive social spending. These policies brought about significant successes. Unfortunately, the model of development being pursued proved unsustainable. By the 1970's Jamaica found itself in deep economic crisis caused primarily by the increase in world oil prices, expansionary fiscal policies, and entrenched labour unions (Meditz et. al. 1987). This opened the way for the involvement of the IMF, and other international financial institutions in its economic management in a very significant way up to present time (Melville, 2002). The Fund first arrived in Jamaica in 1977 and maintained a lending relationship with the country for several years before adopting a non-lending monitoring role (Henry 2012). Whereas loans from the IMF are not available to the Government for project spending, it was anticipated that borrowing from the IMF would create a platform for investment inflows which would lead to economic growth and development. This however was not the case, and the results of signing an agreement with the IMF has proven to be devastating for Jamaica. According to the Global Exchange (2011), the IMF now acts like a global loan shark, exerting enormous leverage over the economies of several countries. These countries have to follow the IMF's policies to get loans, international assistance, and even debt relief. Thus, the IMF decides how much debtor countries can spend on 
education, health care, and environmental protection.

Johnston and Montecino (2012) state that the economic policies implemented under the auspices of the IMF, damage Jamaica's recent and current economic prospect. They state that the IMF policy mix risks perpetuating an unsustainable cycle where public spending cuts leads to low growth, exacerbating the public debt burden and eventually leading to further cuts and even lower growth. The IMF agreement put particular emphasis on controlling the wage bill which can have negative consequences for a developing country that needs to increase spending on vital sectors such as health and education (Johnston \& Montecino, 2012). In addition, the short time frame given for repayment of the loan meant there was no time to invest in order to direct profits toward clearing the outstanding debt (Bank of Jamaica, 2007).

The Fund's basic principles stipulates that, foreign companies have the freedom of choice to participate in any local market by importing goods or by establishing a local production facility, foreign firms should be governed by the same laws and have the same rights in any country as do domestic firms, and that foreign firms be allowed to undertake any activity in any country that is legally "permissible" for domestic firms (Korten, 2001). Whitter (2012) pivots that the IMF led the campaign to liberalise the Jamaican economy, arguing that the free play of market forces would promote the growth of the economy. The record of extremely low growth, less than one per cent per year is evidence that these projections were overly optimistic.

Due to opening up of its border for free trade, Jamaica's small farmers and businesses were forced out of the market completely because they were simply incapable of competing with the international 
market (BOJ, 2002). Imported food and goods are cheaper than those produced locally. Where rural farmers once held property, protected by the state and used predominantly for subsistence, private entities often representing investments from wealthy nations have bought the land for profit based agriculture and tourism. The shift from subsistence agriculture to cash-cropping has bankrupted Jamaican small farmers and has driven them from their land (Bales, 1999, Kramer, 2004). Hence unemployment has increased drastically and some people are left destitute in Jamaica.

Even for those who are employed life can be very difficult. Women are exploited and subjected to sweatshop conditions in the Free Trade Zone (Borrelli, 2002). The free zone located in Jamaica is owned by multinational corporations such as Hanes and other American clothing companies that operate worldwide. Wages in these operations are extremely low often with no guarantees of long-term employment. Owners are not loyal to the country and when production becomes too expensive or can be done more cheaply somewhere else, the companies leave.

For all loan agreements with Jamaica, the IMF has called for reducing the government's Budget deficit Whitter (2012). Inevitably, this means increasing taxes and reducing non-debt expenditure on social services and economic development projects. Allied to this is the sale of public enterprises in order to raise revenue, as well as to reduce the role of the State in the economy. Whitter stresses that the momentum of these agreements has shifted the focus of the Jamaican State away from social and economic development to repayment of debt. The IMF has put the global economy on a path of greater inequality and environmental destruction. Whitter, (2012) points out that the IMF always asks for exchange-rate flexibility, which means reducing the value of the Jamaican dollar. This always drives up the costs of imports, but never stimulates Jamaica's traditional exports. Which means the country will always spend more than it earns therefore continuing the vicious cycle. 
One of the motivational factors for Jamaicans engaging with the fund is that it will help unlock critical financing from other multilateral institutions (Johnston and Montecino, 2012). This was made clear by former finance minister Audley Shaw in his presentation in the 2011/2012 budget. Rather than citing the direct economic benefits of the IMF, Shaw noted the positive signal it would send to their international partners, the Inter American Development Bank, World Bank, European Union and the Caribbean Development Bank. Shaw notes that all these organizations "use the quarterly IMF reviews as the primary conditionality to be met prior to disbursements of grants and loans" (Shaw, 2011 p. 33). Since there were no IMF reviews for Jamaica in 2011 international support for Jamaica was severely curtailed. These additional resources would have been valuable to Jamaica on their own terms and their delay is likely to have further weakened Jamaica's economic growth.

The IMF's structural adjustment policies (SAPs) ensure debt repayment by requiring countries to cut spending on education and health; eliminate basic food and transportation subsidies; devalue national currencies to make exports cheaper; privatize national assets; and freeze wages. Such belt-tightening measures increase poverty, reduce countries' ability to develop strong domestic economies and allow multinational corporations to exploit workers and the environment. Today the Jamaican economy is still struggling with the aftermath of stipulations set by the IMF.

Migration as a survival strategy in Jamaica

Bakker (2009) states that, Caribbean societies have a high degree of mobility, exporting the largest proportion of its population in percentage terms, in the world. According to Ferguson (2007) it is the socio-economic conditions in Jamaica that have contributed to the large out-migration for work. Caribbean people have sought employment opportunities by moving within the region, to the United States, Canada, or former colonial powers such as the United Kingdom and France (Glennie and 
Chappell, 2010). The "culture of migration" has been a means throughout the Caribbean for its people to seek better economic and educational opportunities. It has become one of many survival strategies used by Jamaican households in times of difficulty and environmental stress.

The long history of Caribbean migration, started with forced movement during the colonial times in the 17 th, 18th and 19th century. With a high propensity to move from the sugar plantation system of the island after emancipation, and with opportunities for migrating to the wider Caribbean, significant movements took place to those locations. People moved readily even though they engaged in work similar to what they did prior to migrating (Thomas-Hope, 2003). With the proliferation of banana plantations in Latin America, many Jamaican peasants migrated to larger countries like Panama and Costa Rica, in search of employment and better wages. Many Jamaicans also moved to work on major construction projects such as the trans-Isthmian railway and the Panama Canal while others moved to Cuba to provide labour for the expanding sugar production there. Thus began a vital feature in Jamaica's economy which has lasted to the present day; that of remittances to poor and unemployed relatives from Jamaicans living and working abroad (Bakker, 2009).

In the Caribbean, migration has become the means relied upon to circumvent any negative circumstances that exist in the home country and people are prepared to move whenever the opportunity arises (Thomas-Hope 2003). Today, earning more, sending remittances home, and accessing steady employment have been the main motivations cited for departure by Jamaican migrants (Glennie and Chappell, 2010). Remittances are perhaps the most obvious channel through which migration impacts households, and the amounts of money Jamaican migrants send home have been rising in recent years. Formal remittances as reported by the World Bank totalled about US\$2 billion in 2007, more than double the US\$892 million in 2000 (Glennie and Chappell, 2010). Due to the 
recession in the United States and the United Kingdom, total remittances dropped to about US\$1.8 billion in 2009. The main countries of destination for Jamaican migrants are the United States, Canada, and the United Kingdom, which have established Jamaican communities as well as stronger economies and higher wages than Jamaica.

Why is the CSAWP important for Jamaican migrant farmers, their families and communities? Jamaican workers who participate in the CSAWP want to improve life for themselves and their families. The main reason workers come to Canada under the CSAWP is that they cannot find suitable employment in Jamaica and the work they do here pays more than jobs back home. Reviewing the evidence on the economic and social benefits of migration and remittances for sending countries reveals that migration can generate substantial direct and indirect gains for Jamaica via employment generation, human capital accumulation, remittances, diaspora networks and return migration.

Russell (2009) and Gibb (2007) argue that the temporary migration through the CSAWP forms a 'safety valve' for the Jamaican economy by providing employment and knowledge and skills that the migrant farmers can utilize when they return home. For the seasonal workers, the opportunity to earn Canadian wages provides a welcome strategy to supplement the low incomes and limited employment available in Jamaica where economic conditions have been declining (Brem 2006). This is particularly the case in rural areas affected by trade and other liberalization policies, loss of traditional export markets for sugar and bananas and divestment in small scale agriculture.

Remittances are an integral part of migration and are resilient to any economic recession. This financial aid helps the individual recipients at the micro-level, as well as the government at the macro-level. Remittances reduce poverty of families left in Jamaica, stimulate markets by increasing the demand for 
local goods and services, contribute to investments in human capital, in development, and other productive assets such as enhanced infrastructure (Bird and Deshingkar, 2009). Gibb (2007) points out that temporary migration presents opportunities to improve economic growth through remittances acquired in overseas employment without the permanent loss of skills usually associated with migration. Markova (2010) states that remittance flows do benefit both the migrants' households and the non recipient ones through multiplier effects of spending. Temporary migration tends to be conducive to higher remittance flows than permanent settlement to the host country, especially when it involves low-skilled migrants, not accompanied by family members, who expect to return to their country of origin. The estimated gross annual earnings of Jamaican migrant workers from the CSAWP in 2001 was $C \$ 31.63$ million. In 2005/06 it went up to an estimated C\$44.4 million or J $\$ 2451$ million (Russell, 2007). Remittances from the program to Jamaica, in 2001 were estimated to be C\$7.04 million. In 2004/2005 and 2005/2006 remittances increased to C\$8.95 million and C\$9.77 million respectively (Russell, 2007). The exchange rate of one Canadian dollar to Jamaican dollar is quite high, therefore when money is converted, a substantial amount is sent to Jamaica. In the fiscal year 2005/06, remittances amounted to approximately J $\$ 459$ million or an average of J\$76,564 per person per season. It is hardly likely that small farmers remaining in Jamaica will earn this amount of money in such a short period of time. The multiplier effects of these earnings are very significant to the Jamaican economy (Russell, 2007).

According to the Growers Newspaper of Ontario 2011, while in a meeting in Niagara, Alvin McIntosh, permanent secretary in the Ministry of Labour, Jamaica, highlighted and praised the positive impact of remittances sent by migrant farm workers from Canada on family and community life in Jamaica. Doing farm work in Canada means that workers can build their own homes with improved facilities in Jamaica. Improvements in family's financial status enable them to afford better health care and better 
education. Migrant farmers can send their children to school longer; as a result, the children of CSAWP workers are able to get better jobs in Jamaica. Some Jamaican farm workers use their earnings from Canada to set up or expand small businesses (Gibb, 2007). In addition, Jamaican seasonal migrant workers bring home with them know-how and a different way of doing things that can influence ideas. Seasonal migrants are often conduits of knowledge, skills, technology, fashion, and news which they share with their families and communities, therefore, enhancing changes. 


\section{Chapter 4a: METHODOLOGY, ANALYSIS AND DISCUSSIONS \\ Methodology: The use of newspapers in research}

The news media are recognized as among the world's most influential and powerful institutions. According to Crossman (n.d.) researchers can learn a great deal about a society by analyzing cultural artifacts such as newspapers, magazines, television programs, or music. Researchers who analyse cultural artifacts are not studying the people, but are studying the communications the people produce as a way of creating a picture of their society. Hall (1977) states that, mass media plays a vital role in shaping public discourse and raising anxiety about social and economic change, therefore, news media coverage is an important source of information and can frame discussions on the social and economic developmental impact of the CSAWP among the general public in Jamaica. Media coverage has the potential to affect individual attitudes, behaviours and views of the program.

In the research which follows, I conducted an analysis of Jamaican newspaper coverage and examined media representation of the developmental impact of the CSAWP on Jamaican farm workers, their families and communities. I concentrated mainly on the contents and narratives presented in newspaper stories to get a better understanding of how the CSAWP is viewed by mainstream media and presented to public opinion in Jamaica.. I seek to explore not just what journalist, media commentators and editors say about this issue, but also what media reports politicians to be saying about migration and development in general and in particular I seek to ascertain how powerful voices in the newsprint media represents the benefits of the CSAWP to Jamaica. The analysis was restricted to Jamaica's' two most popular daily newsprint media, the Jamaican Gleaner and the Jamaican Observer. These newspapers were selected because they are the most visible and substantial newspapers. They provide 
coverage of national, regional and international news and features in depth reports on issues affecting Jamaicans. They were also chosen for their large circulation, both news papers are sold throughout the island and they are read by a wide cross section of individuals from various backgrounds.

For analysis, my research focused on articles published between January 2005 and March 2013. In order to get a broad overview of the coverage an overall period of eight years was chosen. Articles were located using the newspapers' websites; a unique combination of search words was used to generate a sample. The search words included; seasonal, temporary, migration, migrant, Jamaican migrant, benefits, development, CSAWP. The articles identified by the key words search were skimmed for their contents and if the information related to the topic they were selected for a second reading. I then re-read each article and selected for inclusion in the analysis only those articles that dealt with migration, the CSAWP, and articles highlighting the negatives and positives of the program to Jamaican migrant farmers. The headlines and the bodies of the articles were examined. I looked at what the Jamaican government, Jamaican migrant farm workers, Canadian employers and activists had to say about the program. I also looked at information that was portrayed in photographs.

Articles were printed and manually colour coded by hand. For each story included in the analysis, I coded for several variables, including the date of publication, its primary focus and themes. Coding focused on a variety of frames; I defined a frame as any argument for or against the program. Most often, these were quotes from politicians, employers, members of interest groups, citizens, or immigrants themselves explaining what they thought about the CSAWP and in what way it impacted their lives.

In the second section I looked at what academics had to say about the cost and benefits of the CSAWP 
to Jamaican migrant farmers, their families and communities.

\section{Media representation of Jamaicans perspective on migration}

Migration has been a central feature of Caribbean life for over one and a half century. The earliest inhabitants migrated to avoid reminders of the plantation system, but present day migration is largely motivated by economic reasons. Jamaicans initially migrated to other areas within the Caribbean, however, in the last few decades they have migrated internationally. According to an article in the Jamaican Gleaner titled, "Migration and Development in the Commonwealth":

"The Commonwealth itself is the end product of migration which spans many centuries, earlier period of forced migration and settlement in the colonies, followed by massive intraCommonwealth migration and changing levels of intensity during the last few decades to international locations" (Patterson 2010).

This article unlike others which looks at economic factors and pressures, seems to naturalize migration or make it sound innate to the Jamaican history, culture and mindset. It goes on to say that:

For Caribbean people, migration has become a cult transcending class, age, gender, colour or professional category. It is as though there is an irresistible urge to migrate within the region or to the metropolis (Patterson 2010).

Some authors in the newsprint media emphasize that it is due to the harsh economic climate in Jamaica that put people in a desperate position and causes them to migrate. A sense of economic crisis is a recurrent theme in newspaper reports on international migration from Jamaica. $14.2 \%$ of the population is unemployed and $16.5 \%$ live below the poverty line therefore, Jamaicans migrate as a form survival strategy. The narrative articulated in this theme observes that the decision to migrate may be a conscious choice to improve the income prospects of the household and to reduce risk associated with income instability. Jamaicans want to be in a better position to take care of themselves and their family 
members. This is highlighted in an article in the Jamaican Gleaner:

It has become a fairly common trend for people to migrate to the US, Canada or UK in order to seek greater opportunities. Almost every Jamaican family has at least one person who has left Jamaica to live elsewhere. When people are asked if they would migrate to another country and why, the most frequent answer is "yes", and nearly everyone admits that they would migrate to increase the chances of a more financially stable future for themselves and their families (Jamaican Gleaner 2012).

This narrative underlines the fact that the dismal outlook of Jamaica's economy has caused some Jamaicans to become disenfranchised. The lack of employment opportunities and opportunities for upward mobility are limited. This narrative recognizes that migration is an attempt to escape the Jamaican economic crisis. The same article continues:

It would be fair to assume that the common notion of the general public is that there are simply no opportunities here in Jamaica. People have repeatedly told others what they would do if they had the chance to leave Jamaica and go to another country. When they speak of this other country, economic wealth becomes a reality and not a possibility. They don't just hope they will be successful, they predict a prosperous life (Jamaican Gleaner 2012).

Another topic covered extensively by the Jamaican press relates to the issue of remittances. Jamaicans who migrate often take care of family members left behind. This is done by sending remittances home either in the form of money or barrels with food items, toiletries or anything that can be useful to the family. Most articles that touched on this issue highlighted that remittances are extremely important to the Jamaican economy as it represents a significant percentage of the country's GDP. The following excerpt from the Jamaican Observer specifies how important remittances are to the Jamaican economy: 
From the days of imperial conquest, those who settled abroad were sending remittances and profits back home to the motherland. So the remittance phenomenon is by no means novel. Remittance average as high as 19 per cent of GDP in Jamaica, these figures exceed the value of foreign direct investment and are vastly more than comes from Official Development Assistance (Patterson 2010).

The positive economic effect of remittances has become a common theme to Jamaican media reporting on international labour migration. It sends a powerful message that global economic inequalities can be met effectively with migration and that migration and development are interdependent processes.

\section{Media representations of the Canadian Seasonal Agricultural Worker program}

Jamaicans have been participating and benefiting from the CSAWP since 1966. The press emphasizes that the program has been praised by successive governments and that they have and will make every effort to remain a part of the program and to expand it when ever possible. Jamaica's Minister of Labour and Social Security, Derrick Kellier is quoted in an article saying:

'The CSAWP has been making a positive impact on the people of the Caribbean since the 1960s'. He reaffirmed Jamaica's commitment to strengthening and expanding the initiative (cited by Pile 2012).

In another article, Minister Kellier stresses the importance of the program to Jamaica's economic development and denounces any effort by Jamaican migrants to give it any bad impression which could affect or halt the development of the program. The article points to a speech the minister gave in Parliament:

"I have gone to some length in enunciating the dynamics of the overseas employment programme, to be able to convey the point that this programme is vital to Jamaica's economic prosperity, and that nothing should be wilfully done to compromise its integrity. Indeed, it 
would be suicidal to do so! I therefore appeal to the Jamaican family, not to kill the proverbial goose that lays the golden egg."

Referring to the CSAWP as the "proverbial goose that lays the golden egg" is a powerful statement in favour of the program. It shows that from the Jamaican government's point of view, the CSAWP is seen positively and is assessed as helpful and profitable for the Jamaican migrant workers.

Another important feature of reporting by the Jamaican print media is that it also focuses on the danger and hardship endured by seasonal migrant workers. Both Jamaican news-papers surveyed highlight this critical perspective of the program. Authors emphasize the criticism of the CSAWP by activists and academics. Criticisms have included but not limited to the working and living conditions of migrants, health and safety concerns, experiences of racism and isolation and migrants' understanding of their ability to exercise rights in Canada. An article in the Jamaican Gleaner represents this narrative:

The agriculture Workers Alliance in Canada has described the treatment of Jamaican migrant farm workers as "Canada's shameful secret" and "indentured servitude". Stan Raper, national coordinator of the alliance, spoke with the Gleaner, describing the relationship between many farm workers as a power imbalance. "Farm workers have little ability to complain and deal with issues affecting them" (Redpath, 2011).

The same article also emphasizes specific health issues related to working conditions associated with the program:

A number of Jamaicans experience harsh living and working conditions, resulting in chronic ailments, some of which are gastrointestinal in nature, or linked to long-term chemical exposure. Farmers experience musculoskeletal injuries, among other conditions, or suffer from climatic extremes (Redpath 2011).

There are several reasons cited as to why migrant workers are not able to improve conditions of health 
and safety in their workplace. If migrant farmers complain of any issues affecting them, they are often seen as trouble makers by their employer. The author of the above mentioned article stops short of acknowledging that the threat of expulsion from the program, deportation from Canada, and the fact that they may not be counted as "named" workers force migrants to remain quiet. Another concern about Jamaican migrant farm workers' health was emphasized by Chris Ramsaroop, an organiser at the Canadian Labour Congress (CLC). He is quoted in an article in the Jamaica Observer as saying that: "Migrant workers are excluded from health and safety legislations. This means they cannot refuse dangerous working conditions, they cannot form joint health and safety committees and they do not have the right to know what dangerous chemicals or work hazards they face" (McLmont 2005).

In spite of some reporting on the challenges associated with the program, most articles I found in both news-papers portray the CSAWP in a positive light and emphasize that it is very popular among Jamaicans who wish to make a better life for themselves and their families. Photographs accompanying newspaper articles tend to reinforce this notion. Pictures in the Jamaican Gleaner show hundreds of Jamaican farm worker applicants waiting to be selected for the CSAWP. (Appendix C)

In addition, many articles present examples of specific individuals to convey the popularity of the program. The Jamaican Gleaner published an article with the following excerpt:

Omar Clarke, of Spring Hill in Portland, has heaped praises on the programme that has acted as a buffer between struggling family economics and relative comfort. "First, the programme is good. I have a lot of things to take care of and it gives a lot of support," he said. In addition to the hardship faced, in six months, Canada will be experiencing winter, something Jamaican farmers don't know much about. Clarke, who will be gone for at least that long, said he was not too concerned. For him, providing for his family was far more important. "I have to provide for 
my family or else somebody will do it for me," he laughed. "But it's not too bad and we have to endure it because a man we name" (Mclean 2009).

Reporters underline that providing for ones family is far more important than any physical or mental discomfort that a migrant farmer may feel. It is suggested that in the capacity as the head of the household one has to do whatever it takes to provide for the family. Even though there is evidence of substandard living and working conditions, news print media point out that higher wages and the extra income earned in Canada enable farmers and their families to increase their level of consumption and live a relatively comfortable life.

The CSAWP is represented by the Jamaican media as extremely beneficial to the migrant farmer as well as the Canadian employers. According to the author of this excerpt, the CSAWP is presented as providing a win- win situation. The assurance of a reliable source of income, in the form of foreign exchange, is a major attraction to many who would otherwise have remained unemployed at home. The workers can pursue their dream of gainful employment while Canadian employers are assured of a steady and reliable source of labour. They can feel good that their crops are planted and harvested while at the same time enabling families in Jamaica to help themselves. Reporting in Jamaican media tends to connect migration of farmers with the demand for labour in Canada. The media demonstrate a key awareness of the connection between migration and the structural dependence of first world economies on migrant labour. The Jamaican Gleaner reported:

The 46-year-old program provides a long list of benefits to migrant workers and the Canadian farmers. For decades, this program has provided Ontario farmers a steady source of reliable labour as a supplement to local labour. Farmers have realized great benefits from the program for more than 40 years, enabling them to hire staff that would otherwise be extremely challenging to find because of the ongoing shortage of suitable and available local Canadian 
workers. At the same time it gives the seasonal workers well-paying employment, benefits and opportunities not available at home (Jamaican Gleaner 2012).

\section{Media representations of the CSAWP and poverty reduction at the household level}

The newsprint media emphasize that a logical consequence of the migration of workers to participate in the CSAWP is a reverse flow of remittances to support dependent relatives, repayment of loans, investment and other purposes. The rhetoric in the newsprint media supports the view that migrant farm workers are excellent at sending remittances to families left at home. Authors of these newsprint articles have asserted that remittances positively influence welfare and poverty reduction and migrant workers have contributed substantially to the economic and social development of Jamaica.

Jamaica's Former Minister for Labour and Social Security, Pearnel Charles, says the Canada/

Caribbean Seasonal Agricultural Workers Programme continue to make invaluable

contributions to the regional economies by making a positive impact on employment and remittances (Jamaica Observer 2009).

In another article written by Braham (2013) the Minister of Labour and Social Security, Hon. Derrick Kellier, said;

“In 2012 we had a very good year." The Overseas Employment Programme has contributed billions of dollars to the Jamaican economy, quoting figures that show a growth from 2008. The figures revealed that in 2008 there were remittances of CDN\$8.45 million, while by 2012 they contributed some sixteen million, three hundred and fifty six thousand, four hundred and eighty four Canadian dollars $(\mathrm{C} \$ 16,356,484.05)$ or in excess of $\mathrm{J} \$ 1.5$ billion, to the economy.

Remittances highlighted above are compulsory remittances which comprises only $25 \%$ of migrant workers earnings. This is the portion which goes to the government which keeps it for the farmers until they return home. Discretionary remittances which are sent through formal and informal channels are 
not included in this total. With one Canadian dollar valuing over ninety Jamaican dollars it means that migrant farmers are contributing significantly more money to the Jamaican economy. Articles consistently stress superior Canadian wages; an article in the Jamaican Gleaner stresses that:

Seasonal workers employed at Ontario farm operations through SAWP earn up to five times or more than they could in their own countries, which enables them to support their families, educate their children and buy and operate businesses and farms in their own countries (Jamaican Gleaner 2012).

The contribution of remittances to development depends on the uses to which the remittances are put. If the resources are used for conspicuous consumption, there is very little contribution to economic development. On the other hand, if the resources are used for investment, to improve the health and productivity of the society and improve the capacity of children in these households to learn and acquire better education, the development of the society will be enhanced. An important element of this discourse is that Jamaican migrant farmers earn Canadian dollars and are able to send their children to school. In Jamaica only elementary education is publicly funded, high school and college education are a luxury many cannot afford. In an interview conducted by McLean of the Jamaica Gleaner (2009) with Fitzgerald Cameron prior to leaving Jamaica for Canada, it was revealed that for the last 24 years, Cameron has been a part of the Government's overseas employment programme. This trip means a lot to him because he is relying on the money to put his daughters through college.

"Well, I have been going on this programme for the past 24 years. I have benefited so much because I am able to support my family and, most of all, send my daughters to school," said the 49-year-old farmer. "I am glad for this opportunity. It helps me and my family a lot," said

Cameron. Overseas farm-work assignments have been the only way he has been able to afford sending his children to school.

The article goes on to say; 
Cameron's daughter, Keisha, is studying medicine, while Kim-Marie is pursuing a degree in politics and international relations, both at the University of the West Indies (McLean 2009).

The narrative recognizes that development in education is development in the future of Jamaica. The improvement in educational opportunities is beneficial both to the household and the country since this would create better job opportunities and higher wages for the individuals, the country on a whole gets a more educated and productive workforce which would be better able to contribute to the long term development of their country.

In addition, the print media shows that remittances have a positive impact on health. Remittances from seasonal workers provide funding for better quality food, housing and the ability to pay for medical treatments for workers and families when they encounter health problems. An article in the Jamaica Observer highlights this and states:

This programme has provided support to thousands of families, assisted with building their homes, better access to health care and social amenities” (Braham, 2013)

According to the Jamaican media, the CSAWP offers a unique chance for poor Jamaican families to achieve a middle class status. In addition to better educational opportunities and better health care, participating in the CSAWP has given workers and their families improved access to better housing. The Jamaican Gleaner published an article highlighting a meeting between Ken Forth, the president of F.A.R.M.S. and the Prime Minister of Jamaica to discuss the success of the seasonal workers program with the following excerpt:

"What's happened is they have university educated kids; professors, doctors, lawyers and they are educated with money from the foreign worker program. They have basically brought themselves up to the middle class. They have nice houses that they got from their work. It's a 
real success story.

Karyl Walker from the Jamaican Observer also spoke with Glenroy Bailey a Jamaican migrant farmer who describes his twenty five years on the program as most rewarding. 'I built my house out of farm work; I would encourage other young men who feel there is no hope to join up. It takes hard work to succeed in life' (Walker 2013).

Benefits at the community level

In addition to impacts on the household, there is development at the community level. The print media shows that Jamaican migrant farmers are not only users of consumer goods but they are indeed contributing to development in their communities. Returned migrants working in CSAWP use earnings for the construction of, repair and addition to their homes. During construction, numerous persons from the community are employed to assist with the building. Returned migrants have also started their own businesses in their communities therefore enhancing further employment and therefore community development. Articles in the Jamaican Gleaner and Jamaican Observer highlight this point:

When he gets back, Cameron plans to invest a portion of his earnings into a piece of land he owns. "My plan is to build on a piece of land at home and continue my farming business" (Roxy Mclean 2009)

Another article in the Jamaican Gleaner, illustrates this narrative. Oral Stewart who has been on the program four times states that;

"The money I earn helps me when I get back to Jamaica. I get to build on my own farm from it. Each time I put another $\$ 100,000$ in my farm, it helps me and other people in my community as well because I employ them, enabling them to achieve more and build towards starting their own farm," (Boyd, 2013) 
The investment of remittances in new businesses or into the expansion of existing family businesses is one of the ways that these flows contribute to economic development. Pernel Charles former Minister of labour in an article pointed out that;

Most of the workers who have travelled to Canada have returned as employers; they have come to put back into Jamaica. They've made careers out of this, he recounting the story of one Jamaican worker who recently informed him that he cannot return to Canada because he needs to remain in his country to run the small business he started with money that he raised as a seasonal worker. He is also the owner of three taxis and a mini bus in Jamaica (Observer 2009).

\section{Benefits at the national level}

The media portrays that at the national level the CSAWP provides needed foreign exchange earnings for the country. The newsprint media posits that money earned from the program increases the foreign exchange earnings and increases the net international reserve. According to a government official in the

\section{Jamaican Observer;}

"It would be remiss of me not to acknowledge the immeasurable contribution of the programme to the individual empowerment of thousands of Caribbean nationals, and to the building and growth of our nations in this region." The CSAWP, commonly referred to as the Farm Labour Programme, has "helped to sustain our families and communities, and ultimately our foreign exchange reserves over the years."

Derrick Kellier concurs and states that:

The Jamaican/ Canadian employment programme continues to be a beacon of hope and opportunity for many thousand of Jamaican workers and a vital source of foreign exchange remittance to the local economy. In 2012 alone, it contributed in excess of J\$ 1.5 billion, to the economy. This is a virtual institution worth preserving at all cost. Let us unite to do just this in 
the interest of enterprising Jamaicans who want to better themselves, provide for their families and build their communities and the country of their birth.

This argument concretizes how members of the government view the economic impact of the program on families, communities and Jamaica.

Transfer of knowledge and skills

The media stresses that for the migrant workers who participate in the CSAWP, migration should not be viewed as 'brain drain' but 'brain circulation' because migrants contribute to their homeland with human and cultural capital upon their return. Important networks develop as a result of migration which facilitates the flow of information, skills and ideas which can be used to develop ones community and country in general. Articles in both newsprint media posits that technological transfer and improved productivity are just a few benefits Jamaica see trickling though the labour force due to the CSAWP. Jamaican Gleaner reported:

Head of the Canadian Overseas Employment programme, Ellis Williams, told The Gleaner that she saw the programme as a plus for both parties. "Jamaica, on a whole, benefits from this programme. When you send out a farmer, the experiences gained overseas are vital," "The` farmers would come back equipped with knowledge and share it with other farmers. Foreign exchange comes into play and they learn how to set up greenhouse farming"(Roxroy Mclean 2009).

Another article confirms that the transfer of knowledge and skills benefit Jamaica and emphasized the fact that the program is beneficial for the economy. The article reinforces the fact that farm workers start their own businesses in Jamaica and become employers, therefore enhancing the development of the community and the country. The Jamaica Observer highlights the views of the Minister of Labour 
on the contribution of the program to transfer of knowledge and skills:

He emphasised that the programme helped the rural economy of Jamaica. Mr. Keiller said: "This is as a result of transfer of technology and the investment of resources. Workers come home and apply the modern methods which they have learnt through working overseas. Many of them have also become entrepreneurs themselves and employ persons when they are overseas."

Negative social impacts of the program

The print media highlights the fact that despite the positive developmental impact, migration also has a negative impact on Jamaica. While remittances have a positive financial impact on the economy and allowed parents to provide better financially for their children, sometimes the means to that end rupture the fibres of family life. The media reveal that, there were mental health and social consequences of migration that ought to be taken seriously. In an article in the Jamaican Gleaner, University of the West Indies lecturer Dr. Audrey Pottinger revealed that Jamaican children whose parents have migrated are more susceptible to depression and suicide. Children's Advocate Mary Clarke states that:

"They really go through a lot. The trauma of separation, the trauma of being left with relatives they hardly know, the trauma of being shifted from one relative to the other, can affect their development," (Jamaican Observer, 2008).

Another article in the Jamaican Gleaner illustrates that;

"For the child who is left at an early age, the memory of the parent fades. The child who is left at the latest stage experiences fear, anger, resentment and rejection" (Reid 2008).

In spite of this negative attribute of migration, the media highlights the CSAWP as extremely valuable 
to the Jamaican people. Social mobility, increased potential for consumption and a better life are some of the benefits that Jamaican migrant farm workers create for themselves and their families. Migrants are able to improve their standard of living and quality of life through participation in the program. 
Chapter 4 b: THE COST AND BENEFITS OF THE CSAWP FROM THE PERSPECTIVE OF

\section{$\underline{\text { ACADEMICS }}$}

The CSAWP is widely researched and various challenges and opportunities are associated with the program. Even though each researcher approaches the topic in a unique way, most emphasize the lack of social rights of migrant workers under the CSAWP. Russell's (2009) research points to the terrible working conditions of Jamaican migrant workers and highlights the disadvantages of the program. At the same time, however, it also looks at the positive contributions this program offers. Basok (2002) focuses on the limited rights and tenuous conditions of work of migrant workers under the CSAWP. She provides a strong argument that contract labour in the Canadian agricultural sector is 'unfree' in other words 'captive labour'. She claims that migrant labourers live in constant fear of expulsion or deportation from the program. She compares the program to slavery as workers are chained to the job by the program's condition to stay with a single employer, which forces migrants to accept substandard working and housing conditions.

Prebisch and Grez (2010) argue that the working conditions in agriculture are socially created through low wages and a poorly regulated labour environment partly enabled by the immigration policies and the denial of citizenship rights to migrant workers. They argue that farm work is at the bottom of the occupational ladder. According to these researchers, agriculture is less regulated than other sectors, as farm workers have historically been excluded from the protections other workers enjoy, including the right to be unionized. Kelly et al (2000) point to the exclusion of temporary workers from some provincial labour standards legislation such as the Occupational Health and Safety Act and the Employment Standards Act in Ontario. In addition, they state that there is also the problem of paternalistic relationships that subordinate foreign workers to their employers and make migrant labour 
readily available at command.

Bindford (2003), Downes and Odle-Worrell (2003) and Russell (2009) focus on the economic aspects of migration, such as, community development with remittances. Bindford looks at the relationship between labour sending countries, reasons for migration and the developmental impact of remittances on migrant workers home communities. For Jamaican migrant workers participating in the CSAWP, remittances fall into two categories, the compulsory saving scheme (CSS) and discretionary remittance.

Jamaican workers are required to remit $25 \%$ their earnings to Jamaica under the Compulsory Savings Scheme (CSS). The government retains five percent of the funds for administrative expenses while the rest is saved for the workers until they return home (Gibb 2007). In addition to mandatory remittances, there is the discretionary remittance where workers send home money frequently to support their families. Approximately $19.6 \%$ of earnings are sent to Jamaica as discretionary remittances (Russell 2007).

\section{Impact of remittances at the household level}

At the household level in Jamaica, remittances often have a positive development effect. According to MacLellan (2009) migrants' earnings directly benefit some families by constituting more than 50 percent of their household income. He states that remittances have been playing an important role in developing countries by boosting economic growth and reducing poverty as well as enabling the recipient family to increase consumption. He claims that remittances alleviate the hardship of poverty by supporting family budget and basic consumption.

Due to improvement in their financial status, families can afford better health care in Jamaica. 
According to a case study done by McLaughlin (2009) on migration and health of Jamaican migrant workers, remittances provide funding for health-related initiatives and treatments as well as income which supports the promotion of related social determinants of health for example nutritious food, education and poverty reduction. She claims that health and safety awareness training provided to migrants, either in pre-departure information sessions or while abroad, may contribute to improving health practices in their homes and communities. McLaughlin (2009) posits that Jamaican migrant workers, particularly those who have migrated over multiple seasons, are able to afford to pay for medical treatments for themselves and families when health issues arise.

According to Russell (2007) households receiving remittances are less likely to send their children to work and more likely to send them to school. Of the discretionary remittance sent by migrant workers to Jamaica, $35 \%$ is invested in children's education. Russell states that investment in education is investment in the future development of Jamaica. According to MacLellan (2009) the CSAWP has long-term development outcomes in Jamaica; in particular, the children of migrant labourers are likely to stay in school longer. According to Kramer 2004, the seasonal agricultural worker's program may help the workers' families to escape the cycle of poverty by enabling their children to pursue higher education and better paying jobs (Kramer, 2004).

Louka (2006) states that a further potential benefit of remittances to the family, is that these transfers may also act as a form of insurance. Jamaica is prone to natural disasters such as hurricanes and earthquakes. The idea is that when the family left at home hits hard times for some reason beyond their control, a member who has migrated to a setting where his or her livelihood remains in-tact during these hard times can transfer support home in the form of remittances. 


\section{Effects at the community level}

According to MacLellan (2009) increased household consumption especially in the form of expenditure on health, education and family welfare contributes to human welfare and capital development at the community level. Downes (2007) states that return migrants working in Canada use earnings for the construction, repair and additions to their homes. During the construction phase building materials are bought from the hardware store and numerous persons from the community are employed to assist with the construction. Louka (2006) states that, there are a number of routes through which the macroeconomic effects of remittance inflows can and do benefit the wider community and not just those families directly receiving the transfers. One such important route is through any multiplier effects of spending by the recipients. That is, the spending of remittances may generate incomes for those providing the goods and services purchased, and they in turn spend this income, setting off a chain reaction.

\section{Effects at the national level}

According to Veena (2003) the Jamaican Government uses the compulsory saving scheme as an effective tool for attracting a portion of the workers net farm earnings into the domestic banking system. She states that money is sent directly to the Bank of Jamaica, which then instructs the banks in which workers hold their savings to credit the account with the Jamaican currency. Banks then disburse the deposit in the form of loan to credit worthy borrowers. Therefore, at the national level, the country benefits from CSAWP through the compulsory saving scheme in terms of balance of payments as well as in terms of remittance related commercial loan to the private sector.

Remittances from migrant farmers bring not only additional income but also an infusion of foreign 
exchange. For the Jamaican economy where imports are high relative to foreign exchange reserves and there is a high level of debt, any addition to foreign exchange availability can prove very valuable (Russell 2007). Another benefit to the country is that the migration of unskilled and semi-skilled workers eases the pressure on the government to create employment for these individuals. As a result, the program minimizes the threat of social unrest among young inactive employable male populations, therefore, maintaining stability in the country (Ozden 2005).

\section{Transfer of skills and knowledge}

Veena (2003) states that the Jamaican seasonal agriculture workers are a potential development resource by the farming expertise they acquire in Canada. Russell (2009) highlights that some migrant workers acquired skills, in technical areas such as chemical and weed control, insect and disease control and application of fertilizer through drip irrigation technology. Veena argues that some farmers are already applying some of the farming skills, knowledge and expertise on their own cultivation. She points out that workers were not averse to sharing their expertise with other farmers who have never participated in the CSAWP.

Veena (2003) states that in the absence of community wide irrigation systems some migrants have constructed household system complete with collection tanks for supplying water through plastic tubing to the fields in order to improve crop yields. These farmers produce a surplus that is sold in the community and in the local market. She points out that other agricultural changes include the planting of new crops or the use of new agriculture techniques. Those who had worked in Canada had enough disposable income to try non traditional crops such as strawberries and to purchase and utilize more appropriate fertilizers. 


\section{Social impact of the Canadian Seasonal Agricultural Workers' Program}

The CSAWP also has an impact on migrant and their families, as workers are absent from their families and home communities from six weeks to eight months each year. McLaughlin (2009) points out that some of the less tangible and recognized lasting effects of migration include the impacts on migrants' family lives. Many migrants report returning to strained or broken marriages, distant relationships with their children and physical and emotional scars. During long absences, both spouses may develop other relationships, which can lead to marital strain and also to unwanted pregnancies and the spread of sexually transmitted infections. McLaughlin (2009) claims that children, who spend much of their youth separated from either or both parents, describe a sense of resentment and loss, while migrants lament how their children develop bad habits such as drug or alcohol consumption, poor school attendance or engagement in petty crime in their absence. She states that many migrants and their families report experiencing heightened depression and anxiety in times of separation. In addition, family members left at home must perform tasks that the absent member would normally perform. Sometimes this means that the husband or wife must perform in non-traditional roles and they may take on more work than when their partner is present. 


\section{Chapter 5: CONCLUSIONS}

This research looked at migration and development and especially the impact of the short term labour migration as exemplified by the CSAWP. The aim was to explore the development impacts of the program on the lives of Jamaican migrants', migrants' households, home communities and country. The research based on media content analysis and research done by academics show that the CSAWP had a positive effect on sending households in Jamaica. Even though migrant workers encounter harsh challenges on Canadian farms, for them the positives of the program outweighs the negatives. Besides having an opportunity to work and earn income, the return migrants have benefited from new skills and experience gained abroad.

It was highlighted that the CSAWP has increased remittance income of some households and this money is used productively. Households have accumulated more assets, increased consumption, have either built or made improvements to their homes and made major purchases of durable goods. The program has allowed migrants and their families to improve standard of living by providing income for better health care. New knowledge is also obtained through health and safety awareness training, either in pre-departure information sessions or while abroad, this knowledge may contribute to improving health practices while in Jamaica. Remittances have also improved school attendance for older children attending high schools, colleges and universities, in addition, migrants are also able to start up small businesses like shops and transportation services.

Community level effects were modest but positive via the multiplier effect. Communities have received benefits in terms of spending patterns of return migrants and their families and investments they have made which creates employment. In addition, at the nation wide level, remittances from the program 
increase the foreign exchange reserves. The country benefits from CSAWP through the Compulsory Saving Scheme in terms of balance of payments as well as in terms of remittance related commercial loans to the private sector.

In terms of skills transfer, there is the realization of greater productivity consciousness and some farmers were using new skills learnt in their farming activities back home. Some farmers applied the skills of irrigating their crops and planting non traditional crops like strawberries using knowledge they had acquired from their work on Canadian farms. The migrants' were also able to gain relatively better social status because of their ability to contribute financially to community work.

However, there are some social problems arising from participating in the program. Community leaders complained that there were issues of child neglect while academics highlight other problems like extramarital affairs which can lead to unwanted pregnancies and the spread of sexually transmitted infections and family breakup. Other social problems include heightened depression and anxiety in times of separation. 


\section{RRECOMMENDATIONS}

Seeing that the CSAWP is so beneficial to migrant workers, their families, communities and the country's development, the Jamaican Government must play a greater role to enhance the lives of these farmers. The government should increase the supervision and regulation of the program and engage in international cooperation in the interest of promoting their rights and preventing abusive conditions. The Jamaican Government also needs to develop creative ways to utilize both the financial and human resources provided by these farmers. Migrant farmers should be made more aware of investment options which they have. For example they can invest their money in high yield accounts which would give them better returns on their investments. Loans with relatively low interest rates should also be made available to these farmers so those who want to can start their own small businesses.

The Ministry of Agriculture and the Rural Agricultural Development Authority (RADA) could be more proactive in utilizing the expertise of these farmers. In order to maximize the agricultural technological transfer that takes place between Canadian farmers and migrant workers, demonstration farms can be established in selected areas of Jamaica. On these farms, they should implement appropriate technologies and conduct farmer training programs. Migrant farmers could work with farmers who have not been on the program and pass on their knowledge. These demonstration farms must be managed efficiently, with the application of appropriate technologies, farmers will observe that production can be increased significantly. In addition, this would ensure that farmers are gainfully employed while they are in Jamaica. 


\section{Appendix A}

Jamaica's newsprint media showing positive and negative opinions of the CSAWP

\begin{tabular}{|c|c|c|c|}
\hline $\begin{array}{r}\text { NEWSPAPER ARTICLES } \\
\end{array}$ & POSITIVE & NEGATIVE & YEAR \\
\hline \multicolumn{4}{|l|}{ Jamaican Gleaner } \\
\hline Farm workers praise Canada/Caribbean program & $\mathrm{X}$ & & 2013 \\
\hline Seasonal farm worker program prepares for labour influx & $\mathrm{X}$ & & 2012 \\
\hline Caribbean committed to Canada/ Caribbean farm program & $\mathrm{X}$ & & 2012 \\
\hline Farm work program a blessing to Jamaican families & $\mathrm{X}$ & & 2009 \\
\hline $\begin{array}{l}\text { Statement to Parliament on the overseas employment } \\
\text { program }\end{array}$ & $\mathrm{X}$ & & 2013 \\
\hline Seasonal workers provide necessary agriculture labour & $\mathrm{X}$ & & 2013 \\
\hline Eyeing jobs overseas? Hopes up for 2010 & $\mathrm{X}$ & & 2010 \\
\hline 172 workers leave for Canada & $\mathrm{X}$ & & 2013 \\
\hline $\begin{array}{l}\text { Seasonal workers program continues to benefit farmers and } \\
\text { workers }\end{array}$ & $\mathrm{X}$ & & 2012 \\
\hline $\begin{array}{l}\text { Canada/Caribbean seasonal agriculture workers program } \\
\text { continues } \\
\text { to assist regional economies }\end{array}$ & $\mathrm{X}$ & & 2009 \\
\hline Migrant workers stripped of benefits & & $\mathrm{X}$ & 2012 \\
\hline Poor working conditions 'Canada's shameful secret' & & $\mathrm{X}$ & 2011 \\
\hline Hurdles in treating Jamaican farmers & & $\mathrm{X}$ & 2011 \\
\hline $\begin{array}{l}\text { Farm work danger - Canadian lobby group wants inquiry into } \\
\text { death } \\
\text { of Jamaican }\end{array}$ & & $\mathrm{X}$ & 2005 \\
\hline Jamaican farm workers die on job in Canada & & $\mathrm{X}$ & 2010 \\
\hline Farm workers suffering in Canada - study & & $\mathrm{X}$ & 2011 \\
\hline \multicolumn{4}{|l|}{ Jamaican Observer } \\
\hline First batch of farm workers leave for Canada & $\mathrm{X}$ & & 2011 \\
\hline $\begin{array}{l}\text { seasonal agriculture workers treated well says program } \\
\text { spokesman }\end{array}$ & $\mathrm{X}$ & & 2009 \\
\hline $\begin{array}{l}\text { Caribbean countries want to send more farm workers to } \\
\text { Canada }\end{array}$ & $\mathrm{X}$ & & 2012 \\
\hline The seasonal agriculture worker program prepares for 2013 & $\mathrm{X}$ & & 2013 \\
\hline "It takes hard work to succeed in life" & $\mathrm{X}$ & & 2013 \\
\hline Canada lauded for its development contribution & $\mathrm{X}$ & & 2011 \\
\hline 2000 more workers in Canada this year & $\mathrm{X}$ & & 2013 \\
\hline Jamaican farm workers die in Canada & & $\mathrm{X}$ & 2010 \\
\hline Vigil in Canada for dead Jamaican Worker & & $\mathrm{X}$ & 2010 \\
\hline Injured farm worker - we are treated like slaves & & $\mathrm{X}$ & 2008 \\
\hline
\end{tabular}


Appendix B

MAP OF JAMAICA SHOWING PARISHES

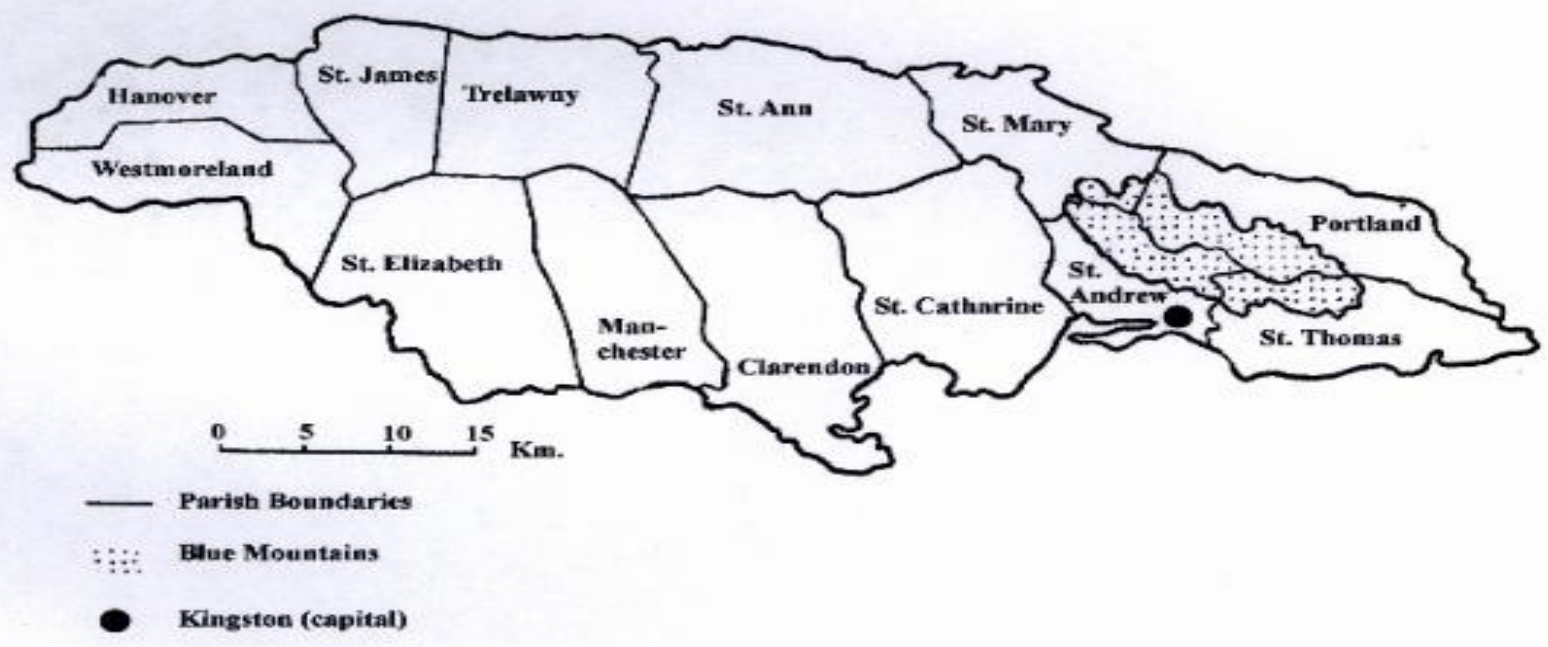


Appendix C Jamaica's unemployment rate



The Image shows Jamaica's unemployment rate over the period 2010 to 2012. Data courtesy the Statistical Institute of Jamaica (STATIN) 
Appendix D Pictures showing the popularity of the CSAWP in Jamaica

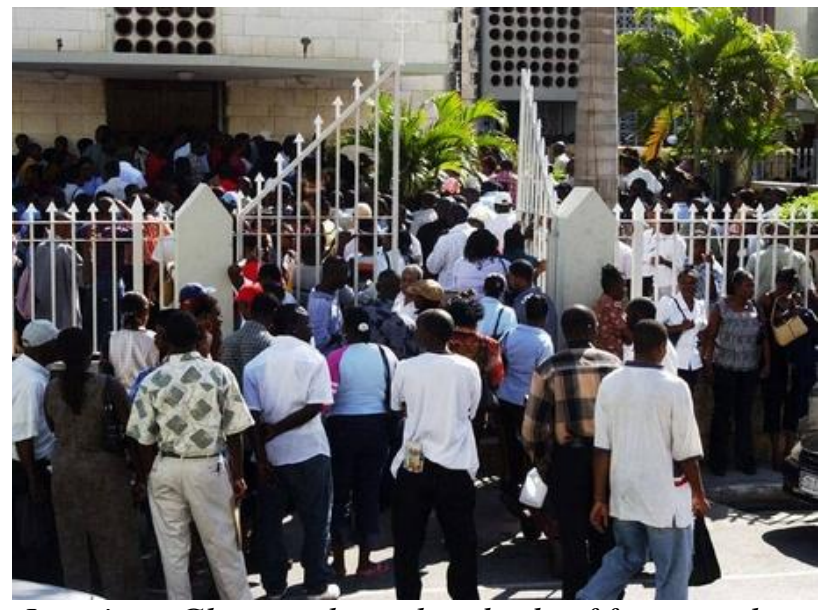

In this 2005 photo, The Jamaican Gleaner shows hundreds of farm-work applicants gather at the St Paul's United Church in Montego Bay, St James, hoping to be selected for the programme (Redpath 2011)

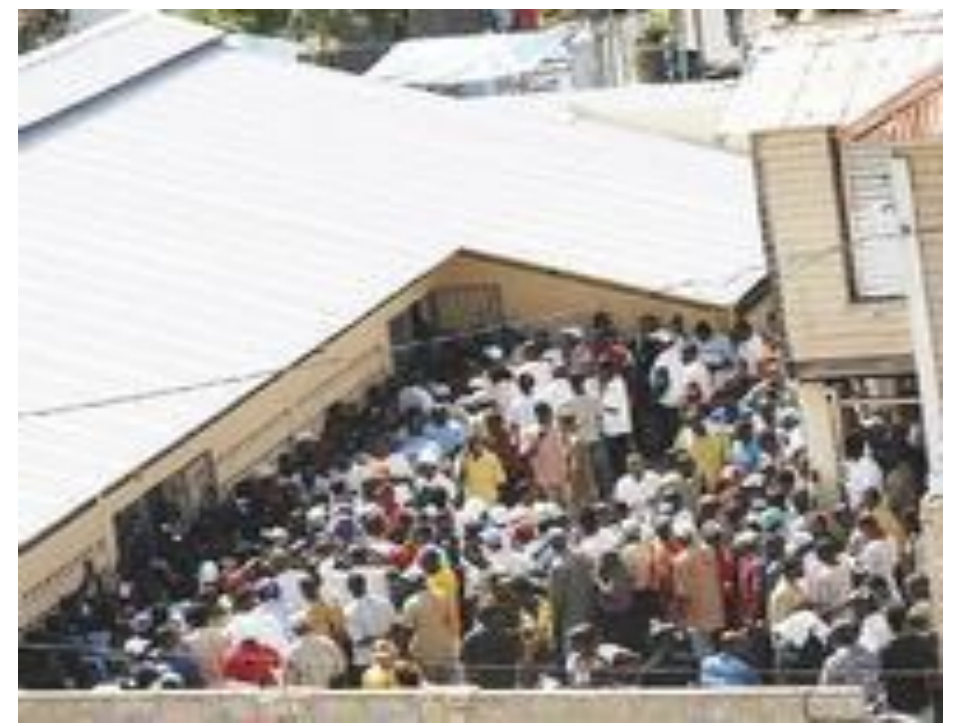

Scores of persons gathered at the Ministry of Labour and Social Security's Overseas Employment Centre at East Street, Central Kingston Jamaica, hoping to be chosen to participate in the Canadian Farm Work Programme. (Jamaican Observer 2006 ) 
Appendix E List of Acronyms

$\begin{array}{ll}\text { BOJ } & \text { Bank of Jamaica } \\ \text { CSAWP } & \text { Canadian Seasonal agriculture Workers Program } \\ \text { CIC } & \text { Citizenship and Immigration Canada } \\ \text { CLC } & \text { Canada Labour Congress } \\ \text { CSS } & \text { Compulsory Saving Scheme } \\ \text { FINSAC } & \text { Financial Sector Adjustment Company } \\ \text { IMF } & \text { International monetary Fund } \\ \text { IOM } & \text { International Organization for Migration } \\ \text { FARMS } & \text { Foreign Agricultural Resource Management Services } \\ \text { FERME } & \text { Foundation of Enterprises for the Recruitment of Foreign Labour } \\ \text { HRSDC } & \text { Human Resource and Skills Development Canada } \\ \text { LMO } & \text { Labour Market Opinion } \\ \text { MOU } & \text { Memorandum of Understanding } \\ \text { NIR } & \text { Net International Reserve } \\ \text { SAWP } & \text { Seasonal Agriculture Workers Program } \\ \text { SAP } & \text { Structural Adjustment Policy } \\ \text { UFCW } & \text { United Foods and Commercial Workers Canada }\end{array}$




\section{$\underline{\text { References }}$}

Bank of Jamaica (BOJ), (2007) Effects of the IMF sanctions on the Jamaican economy http://www.mtholyoke.edu/ beckf20s/

Bakker, C. (2009) The impact of Migration on children in the Caribbean. UNICEF office for Barbados and the Eastern Caribbean. www.unicef.org/barbados/impact_of_migration_paper.pdf

Basok, T. (2002) Tortillas and Tomatoes: Transmigrant Mexican Harvesters in Canada. Montreal \& Kingston: McGill-Queen's University Press.

Basok, T. (2007) Canada's Temporary Migration Program: A Model despite Flaws. http://www.migrationinformation.org/feature/display.cfm?ID=650

Bindford, L (2003) Migrant Remittance and (under) development in Mexico

Borrelli, D. (2002) Neo-colonialism in Jamaica: Neo-colonialism in Jamaica: History, practices, and resistance http://debate.uvm.edu/dreadlibrary/borelli02.htm

Braham A. (2013) 172 workers leave for Canada. http://www.jis.gov.jm/news/opm-news/32654-172workers-leave-for-canada

Campbell, Horace. Rasta and Resistance. Trenton, NJ: Africa World Press, 1987.

Castles, S. \& Miller, M. J. (2003) The age of migration. New York: Guildwood Press

CIA World Fact book (2013) The Jamaican Economy. Retrieved from https://www.cia.gov/library/publications/the-world-factbook/geos//jm.html

Citizenship and Immigration Canada (2009), Facts and Figures 2008, Immigration Overview; Permanent and Temporary Residents, http://www.cic.gc.ca/english/resources/statistics/facts2008/index.asp

Crossman, A. (n.d.) Content Analysis: Understanding society through cultural Artefacts. http://sociology.about.com/od/Research/a/Content-Analysis.htm

De Haas, H. G. (2007). Remittances, migration and social development. United Nations Research Institute for Social Development.

De Haas, H. (2010). Migration and Development: A Theoretical Perspective1. International Migration Review. 
Deshingkar, P., \& Grimm, S. (2005). International Migration and Development: A Global Perspective. Migration Research Series, No. 19, International Organization for Migration, Geneva.

Downes, A. (2007) The Canadian Seasonal Agricultural Workers' Program:

The Experience of Barbados, Trinidad \& Tobago. Ottawa, North south institute http://www.nsi-ins.ca/english/pdf/CSAWP_Andrew_Downes.pdf

Economy Watchcontent (2010) The Jamaican Economy:

http://www.economywatch.com/world_economy/jamaica/

Ferguson, N. (2007) The Seasonal Agricultural Workers Program:

Considerations for the Future of Farming and the Implications of Managed Migration. http://canada.metropolis.net/pdfs/Seasonal_Agr_Ferguson_e.pdf

Flanagan, E. (2009) “The Black Man's Struggle through Colonization”

http://debate.uvm.edu/dreadlibrary/flanagan.html

Flecker, K. (2011). Canada's Temporary Foreign Workers Program (TFWP) Model program - or Mistake Canadian Labour Congress

Ferguson, N. (2007) The Seasonal Agricultural Workers Program:

Considerations for the Future of Farming and the Implications of Managed Migration. http://canada.metropolis.net/pdfs/Seasonal_Agr_Ferguson_e.pdf

Gibb, H. (2006) farm workers from afar: Results from an international study of seasonal farm workers from Mexico and the Caribbean working on Ontario farms. The North South Institute

Gibb, H. (2007) The Temporary Foreign Worker program: Opportunities and Challenges Ottawa, the North-South Institute. http://www.nsi-ins.ca/english/pdf/TWPs_Opportunities_Challenges.pdf

Gibson, J., \& McKenzie, D. (2010). The development impact of a best practice seasonal worker policy. World Bank.

Ghosh, Bimal. 2006. Migrants' Remittances and d Development: Myths, Rhetoric and Realities. International Organization for Migration, Geneva, and the Hague Process on Refugees and Migration, The Hague.

Ghosh, J. 2009. Migration and Gender Empowerment: Recent Trends and Emerging Issues. Human Development Research Paper, No. 4, United Nations Development Program, New York.

Greenhill, D. (2000) Managed Migration best Practices and Public Policy “The Canadian Experience”

Global Exchange (2011) Top Ten Reasons to Oppose the IMF http://www.globalexchange.org/resources/wbimf/oppose 
Glennie, A. \& Chappell, L. (2010) Jamaica: From Diverse Beginning to Diaspora in the Developed World. Institute of Public Policy Research http://www.migrationinformation.org/feature/display.cfm?ID=787

Hampshire, K. (2002) 'Fulani on the move' Seasonal Economic Migration in the Sachel as a social Process, Journal of Developmental Studies

Hanley, Wayne (2007) The status of Migrant farm workers in Canada 2006-2007 http://www.ufcw.ca/Theme/UFCW/files/PDF2007/StatusReportEN2007.pdf

Henry, M. (2012) The Jamaican Gleaner. The second coming of the IMF http://jamaicagleaner.com/gleaner/20120930/focus/focus1.html

IOM, 2011, Migration and Development http://www.iom.int/jahia/Jahia/aboutmigration/developing-migration-policy/migrationdevelopment/cache/offonce/lang/en.

Jamaica Gleaner. (2008) Don't make 'barrel kids' become victims. http://jamaicagleaner.com/gleaner/20080611/news/news5.html

Jamaican Gleaner. (2012) Seasonal farm worker programme prepares for labour influx.

Jamaican Gleaner (2012) No opportunities in Jamaica http://jamaica-gleaner.com/extra/article.php? $\mathrm{id}=1545$ ?

Jamaican Gleaner (2012) Caribbean committed to Canada-Caribbean farm programme. http://jamaicagleaner.com/gleaner/20121205/business/business9.html

Jamaican Gleaner (2012) More jobs expected for overseas employment http://jamaicagleaner.com/gleaner/20120126/lead/lead8.html

Jamaican Observer (2011) First batch of farm workers leave for Canada http://www.jamaicaobserver.com/news/First-batch-of-farm-workers-leave-for-Canada_8277050

Jamaica Observer. (2009) Canada/Caribbean seasonal agricultural workers programme continues to assist regional economies. December 11, 2009 http://www.jamaicaobserver.comCanadaCaribbean-seasonal-agricultural-workers-programme-continues-to-assist-regional-economies982.html

Jamaica Observer. (2012) Jamaica has high rate of Migration among tertiary graduates http://www.jamaicaobserver.com/news/Jamaica-has-high-rate-of-migration-among-tertiarygrads_11874070

Jamlink (2013) Economic Development in Jamaica-1838-1938. http://www.jamlink.com/index.php? task=pdf\&id=255\&option=com_myblog 
Johnston, J. \& Monticeno, J. (2012) Update on the Jamaican Economy, Center for Policy and

Economic Research, http://www.cepr.net/index.php/publications/reports/update-on-thejamaican-economy

Kapur, Devesh. 2003. Remittances: The New Development Mantra? United Nations Conference on Trade and Development, Geneva.

Kellier, D. (2013) Statement to Parliament on the overseas employment programme, Minister of Labour and Social Security the Honourable Derrick Kellier. http://www.mlss.gov.jm/pub/index.php?artid=152

Kelly, N. and Trebilcock, M. (2000) The making of the Mosiac a History of Canadian Immigration Policy, University of Toronto press

King, R., \& J. Vullnetari. 2006. Orphan Pensioners and Migrating Grandparents: The Impact of Mass Migration on Older People in Rural Albania. Aging and Society, Vol. 26, Issue 5, pp. 783-816.

Korten, D. (2001) When Corporations Rule the world, Second Edition, Kumarian Press, Inc., and Berrett-Koehler Publishers Inc.

Kramer, M. (2004) Migrant workers in Ontario, Growing the food we eat. Retrieved from http://www.org/downloads/WPIRG_MigrantWorkersInOntario.pdf

Knowles, K. (1999) The Seasonal Agricultural Workers Program in Ontario: From the Perspective of Jamaican Migrants. Retrieved from http://www.nlc-bnc.ca/obj/s4/f2/dsk2/ftp04/mq24478.pdf

Louka, T. Robert, L. and Xengogiani, T. (2006) The Effects of Migration on Sending Countries: What do we know? OECD Development Centre, Working Paper 250.

Lucas, R. (2006) Migration and Rural Development. Background paper presented at the conference beyond agriculture

Manley, Michael. The Politics of Change: A Jamaican Testament. Washington, D.C. Howard University Press, 1975.

Maclellan, N. Mares, P. (2009) Remittances and Pacific development http://epress.anu.edu.au/ssgm/global_gov/mobile_devices/ch08s02.htm

Massey et. al. (1998) Worlds in Motion: Understanding international migration at the end of the millennium. Oxford: Clarendon Press

Mashayekhi .M, (2009) Contribution of migrants to development: Trade, investment and development linkages, http://www.unctad.org/en/docs/emditctncd_01_en.pdf. 
McLaughlin, J. (2009) Migration and Health: Implications for Development.

A Case Study of Mexican and Jamaican Migrants in Canada's Seasonal Agriculture Workers Program

Mclean, R. (2009) Farm work program a blessing to Jamaican families. The Jamaican Gleaner. http://jamaica-gleaner.com/gleaner/20090416/lead/lead2.html

McLmont, I. (2005) Vigil in Canada for dead Jamaican farm worker. The Jamaica Observer http://www.jamaicaobserver.com/news/31205_vigil-in-canada-for-dead-jamaican-farm-worker

McKenzie, D. (2006) Beyond Remittances: the Effect of Migration on Mexican Households. In "International Migration, Remittances \& the Brain Drain" http://www.childmigration.net/WB_McKenzie_06_2

Meditz, S. W. \& Hanratty, D. M. (1987) Caribbean Islands: A Country Study. Washington: GPO for the Library of Congress. http://countrystudies.us/caribbean-islands/

Melvill, J. A. (2002) The impact of Structural adjustment on the poor, Caribbean Development Bank

Mohapatra, S., Silwa, A., \& Ratha, D. (2010). Outlook for Remittance Flows 2011-12: Recovery after the crisis, but risks lie ahead.

Nicholas, T. (1996) Rastafari. Chicago, IL: Frontline Distribution International.

O'Neil, R. (2003) 'Brain drain and Gain. The case of Taiwan' Migration Information Source Migration Policy Institute, Washington D C

Özden, Ç. and M. Schiff, Eds (2005) International Migration, Remittances, and the Brain Drain. Washington DC, The International Bank for Reconstruction and Development / The World Bank.

Patterson, P. J. (2010). Migration and development in the Commonwealth. The Jamaican Gleaner, October 31, 2010. http://jamaica-gleaner.com/gleaner/20101031/lead/lead8.html

Patterson, P. J. (2010) What migration, remittances are doing to our socities. Jamaica Observer. November 1, 2010. http://www.jamaicaobserver.com/news/What-migration--remittances-aredoing-to-our-societies_8107401

Pile, S. (2012) Caribbean Government laud farm work program. December 6, 2012 http://www.gisbarbados.gov.bb/index.php?categoryid=13\&p2_articleid=9687

Persaud, Randolph B. Counter-Hegemony and Foreign Policy: The Dialectics and Global Forces in Jamaica. Albany, NY: State University of New York Press, 2001. 
Preibisch, k. and Grez, E. (2010) The Other Side of el Otro Lado: Mexican

Migrant Women and Labour Flexibility in Canadian Agriculture. The University of Chicago Press. Vol. 35, No. 2

Ratha, D. (2005) 'Workers remittances': an important and stable source of external development finance. World Bank, Washington D C

Ratha, D. and Mohapatra, S., (2007). Increasing the Macroeconomic Impact of Remittances on Development. The World Bank, Washington D.C. 20433

No http://dilipratha.com/index_files/G8Berlin.pdf.

Ratha, D. (2011) Worldwide Remittance Flows updated to \$483 billion for 2011 http://blogs.worldbank.org/peoplemove/worldwide-remittance-flows-updated-to-483-billionfor-2011

Redpath, L. (2011) Poor working conditions 'Canada's shameful secret'. The Jamaican Gleaner. http://jamaica-gleaner.com/gleaner/20110428/lead/lead6.html

Reid, T. (2008) Paying the price: Despite high remittances, migration is adversely affecting family life in Jamaica. http://jamaica-gleaner.com/gleaner/20080526/lead/lead1.htm

Russell, R. (2009) Jamaican Workers' Participation in the Canadian Seasonal Agricultural Workers' Program. Retrieved from http://www.nsi-ins.ca/english/pdf/Russell_Jamaica_Case_Study.pdf

Russo, R. M. (2012) Solidarity never, Canadians forever: The Seasonal Agriculture Workers Program in Canada

Satzewich, V. (1991) Racism and the incorporation of foreign labour; Farm Labour Migration to Canada since 1945. London and New York: Routledge

Sen, A. (1999) Development as Freedom, Anchor Books, New York

Shaw, A. (2011) From Stabilisation to Growth. Retrieved from www.japarliament.gov.jm/.../608_Budget\%20Debate\%20Presentation

Sorensen, N. N. (2004). The development dimension of migrant transfers. Copenhagen: Danish Institute for International Studies.

Stark, O., \& Bloom, D. E. (1985). The new economics of labour migration. The American Economic Review

Stark, O., Taylor, E, (1989) Relative Deprivation and International Migration Demography Vol 26

Taran, P. A., \& Ivakhnyuk, I. (2009). Economic migration, social cohesion and development: towards an integrated approach. Council of Europe. 
Taylor, E. J. (1996). Development Strategy, Employment and Migration. Organization for Economic Cooperation and Development http://books.google.ca/books?isbn=926414800

Taylor, J. E. (1999). "The New Economics of Labour Migration and the role of remittances in the migration process." International Migration, Vol. 37.

Thomas-Hope, E. (2003) Human trafficking in the Caribbean and the Human Rights of migrants University of the West Indies, Mona, Jamaica

Vargas-Lundius, R., Villareal, M., Lanly, G., \& Osorio, M. (2008). International migration, remittances and rural development. International Fund for Agricultural Development (IFAD).

Veena, V. (2007) The Regulatory and Policy Framework of the Caribbean Seasonal Agricultural Workers' Program. Retrieved from http://www.nsi-ins.ca/english/pdf/Regulatory_Policy_Verma.pdf

Vertovec, S. (2009) Transnationalsim. Routledge: Oxon and New York

Walker, K. (2013) 'It takes hard work to succeed in life'. Veteran farm worker urges young jamaicans to join in. Jamaica Observer. http://www.jamaicaobserver.com/news/-It-takes-hard-work-tosucceed-in-life-_13309183

Waters, Anita M. (1985) Race, Class, and Political Symbols. New Brunswick, NJ: Transaction Publishers.

Whitter, M. (2012) Lessons from the IMF http://jamaicagleaner.com/gleaner/20120708/focus/focus3.html 